\title{
Application of Strontium Isotope Analysis of Bone and Tooth in the Study of Ancient Immigrations
}

\author{
Masoud Bagherzadeh Kasiri ${ }^{1^{*}}$, Akbar Abedi ${ }^{2}$ \\ ${ }^{1}$ Associate Professor, Faculty of Applied Arts, Tabriz Islamic Art University, Tabriz, IRAN \\ ${ }^{2}$ Assistant Professor, Faculty of Applied Arts, Tabriz Islamic Art University, Tabriz, IRAN
}

Received: 08/12/2018

Accepted: 03/04/2019

\begin{abstract}
One of the important questions of archaeology is the study of the mobility and immigration of human groups. A common method for addressing these issues is to refer to the artifacts and archaeological findings left behind by the earlier cultures and to compare the forms, motifs, and production methods used among various ancient cultures, and hence, to explore the relationships and cultural exchanges between the societies. But, in the last three decades, the analysis of strontium isotopes in human tooth and bone samples (and even animals) has made it possible to study ancient immigration using a new method. According to the results of scientific researches, $87 \mathrm{Sr} / 86 \mathrm{Sr}$ in each region is different due to the geological complications and the genus and stony sediments with $87 \mathrm{Sr} / 86 \mathrm{Sr}$ of other regions. By measuring $87 \mathrm{Sr} / 86 \mathrm{Sr}$ in bone and skeletal samples and comparing it with the average $87 \mathrm{Sr} / 86 \mathrm{Sr}$ geological ratio in the region, the samples of the studied skeletons can be either indigenous or migratory. Since the people of the Piranshahr area in Iran have still traffic to the cities of Erbil and Sulaimaniyah in Iraq, and according to the studies, most villagers from Silveh village migrated to this region during the past century from the Iraqi Kurdistan, the immigration study of skeletons found in Tepe Silveh archaeological site could be interesting. The purpose of this study was to use the analysis of stable isotopes of strontium of the teeth and bone samples of skeletons obtained from the archaeological site of Tepe Silveh, Piranshahr, in order to determine their native or migratory nature. Tepe Silveh or as villager named "Tepe Sheikh Esmail Silveh" (N: 36 48' 099" - E: 45 05' 937" - altitude: $1567 \mathrm{~m}$ ) is located exactly $100 \mathrm{~m}$ north of the Silveh village. Tepe Silveh is located in the center of intermountain river valley on the northern margin of the village, which has already been demolished and abandoned. As explained above, the reason for the destruction of the village was the sinking in the basin of the Silveh Dam. Seven Excavation trenches in Tepe Silveh have revealed, important materials from Early Chalcolithic Dalma (5000 BC) culture, Late Chalcolithic, Early Bronze Age culture of Hasan Ali or Nineveh V (3500- 2700 BC), Iron Age and Parthian periods. After a gap, Tepe Silveh have re-settled during Millde Islamic Periods (Seljuk era) and continued up to the late Islamic Period. According to the important location of Tepe Silveh and different occupation of the site deformation from Early Chalcolithic Dalma period to Islamic era, it should be suggested as a particularly important case study of migration, because it has been active and dynamic during different periods. Proximity of the site to the Iran, Iraq and Turkey adds to the importance of this study. To achieve this, the $87 \mathrm{Sr} / 86 \mathrm{Sr}$ of the samples was measured. By comparing the ratio of strontium isotopes, it was possible to determine whether the samples were indigenous or migratory.
\end{abstract}

*Corresponding author: m.kasiri@tabriziau.ac.ir

Copyright $₫ 2020$, the Authors / This open-access article is published under the terms of the Creative Commons Attribution-NonCommercial 4.0 International License which permits Share (copy and redistribute the material in any - medium or format) and Adapt (remix, transform, and build upon the material) under the Attribution NonCommercial terms. 
The results obtained showed the different proportions in the analysis of strontium isotope, so that all samples could be considered non-native. Of course, this comment is only expressed on the basis of these five skeletons, and more specimens and analysis are needed to comment on the archaeological site of Piranshahr.

Keywords: Stable Isotopes Analysis, Strontium Isotopes, Tepe Silveh Archaeological Site, Human Skeleton, Immigration/Mobility or Sedentism 


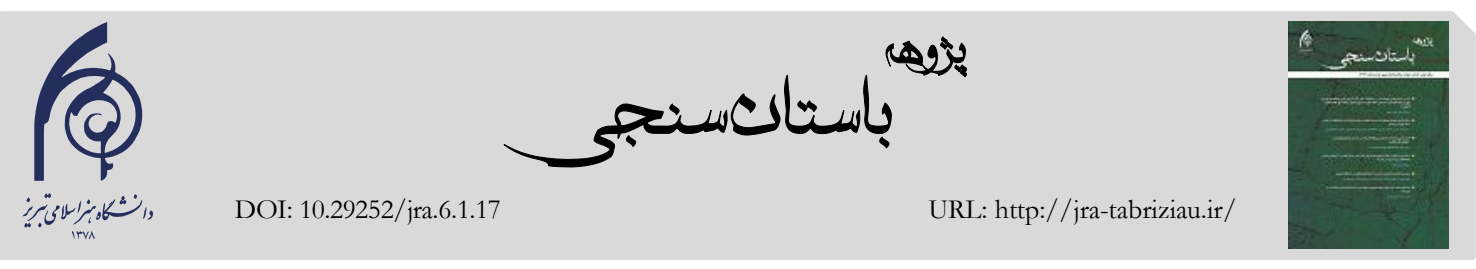

دمالم ِِرَوهشى

كاربرد آناليز ايزوتوبٍهاى استرانسيوم استخوان و دندان

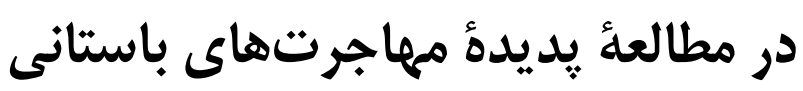

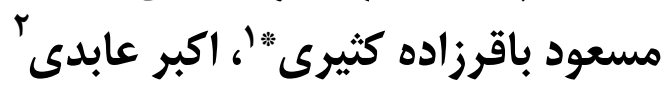

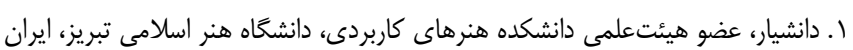

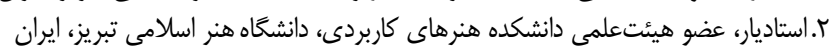

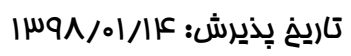

Iساريخ دريافت: IسV/。9/V

\section{جكيده}

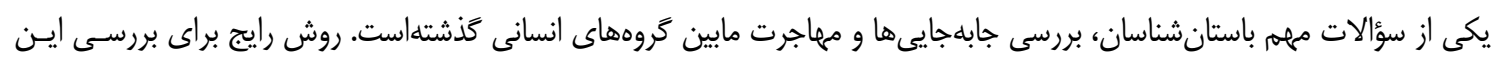

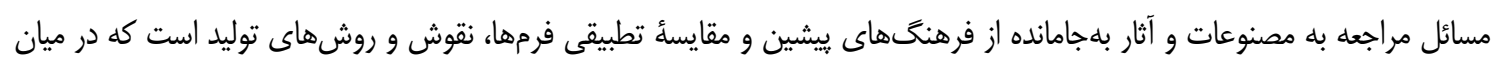

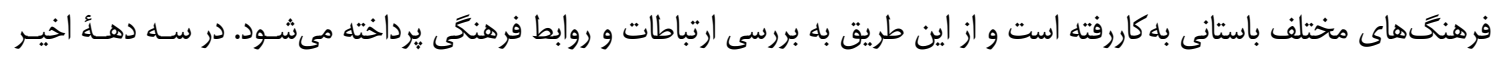

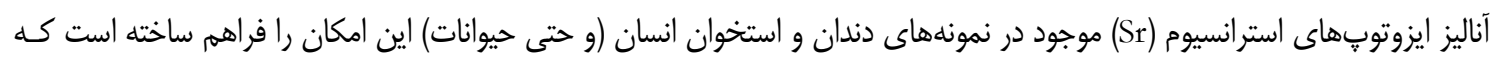

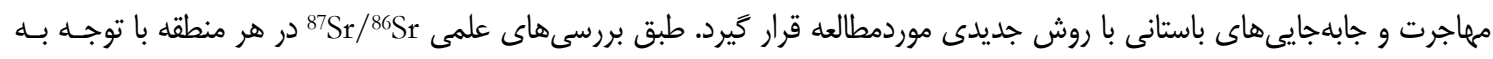

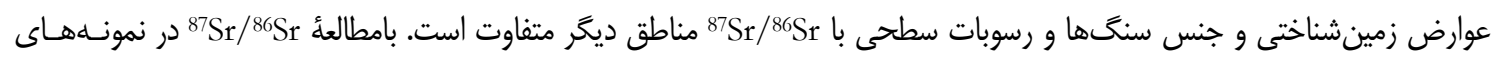

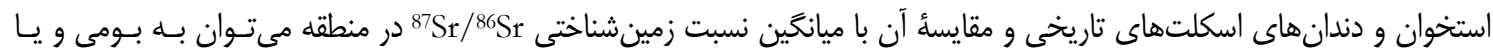

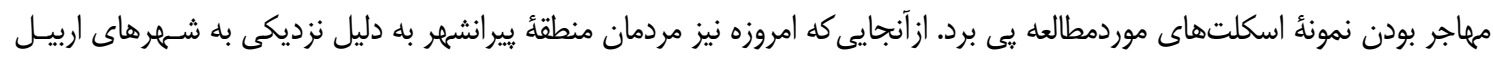

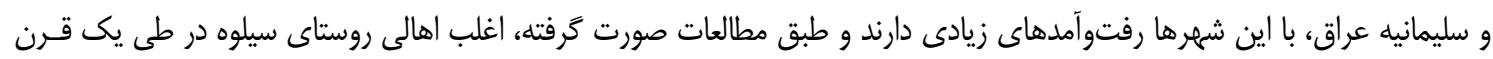

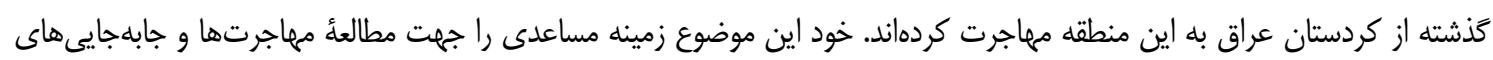

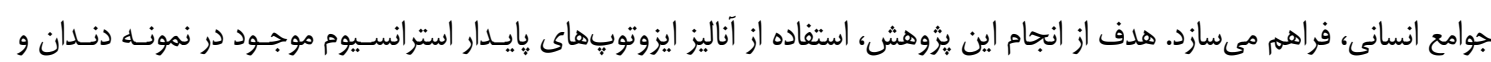

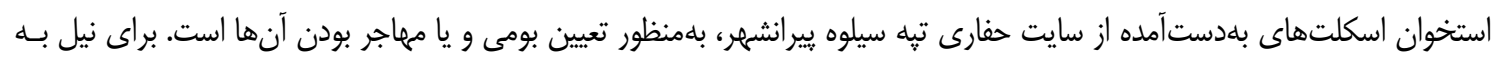

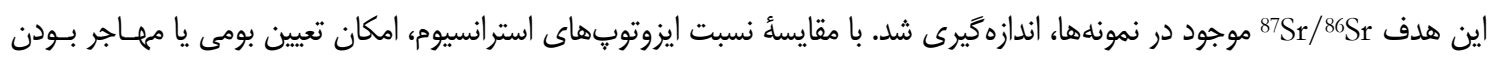

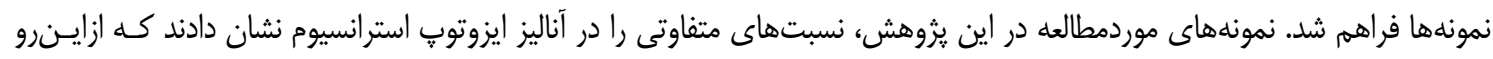

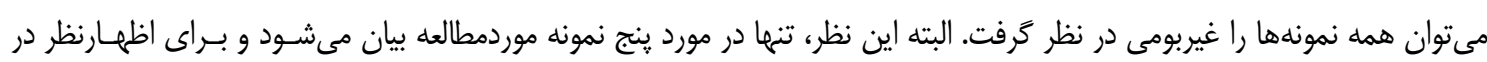

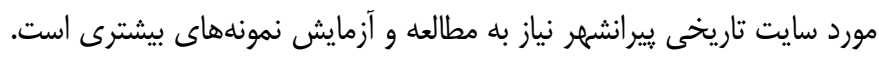

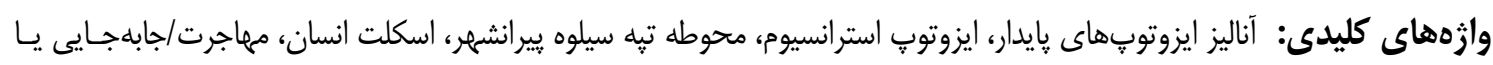

يكجانشينى

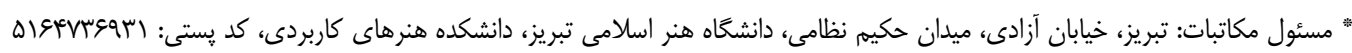

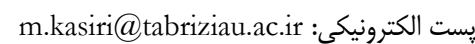
(C) حق نشر متعلق به نويسنده(كان) است و نويسنده تحت مجوز Creative Commons Attribution License به مجله اجازه مى دهد مقاله خاب شده را با ديخران به اشتراك بحذارد منوط بر اينكه حقوق مؤلف اثر حفظ و به انتشار اوليه مقاله در اين مجله اشاره شود. 
غذايى جمعيتهاى ماقبل تاريخ نيز مورداستفاده قـرار مسى

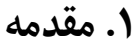

كيرد [6]

يكسى از مهـهمترين مـوادى كـه در اغلـب كـاوشهـاى

يكى از سؤالات مهم باستانشناسى بررسى جابهجايى

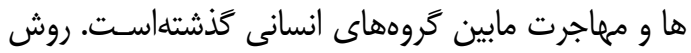

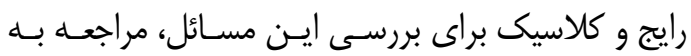

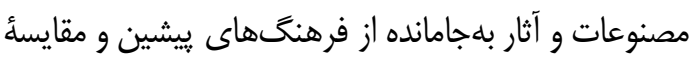
تطبيقى فرمها، نقوش و روشهاى توليد است كه در ميـان

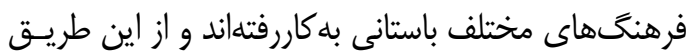

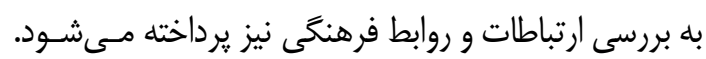

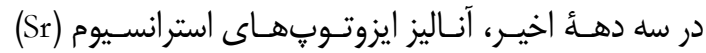

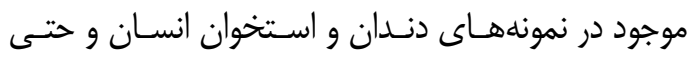

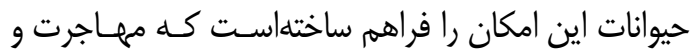

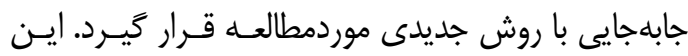

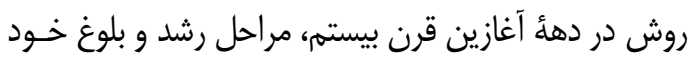

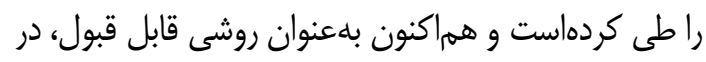

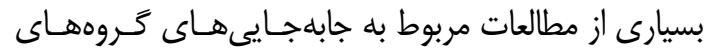
انسانى كذشته مورداستفاده قرار مى كيرد.

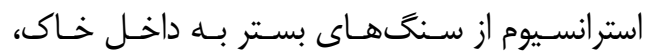

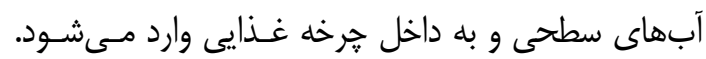

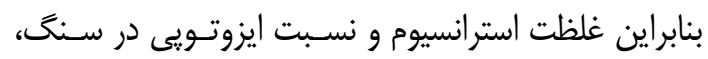

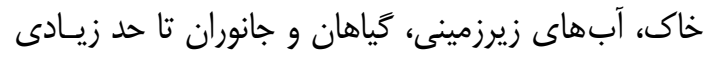

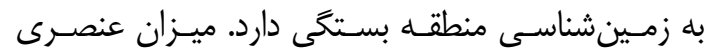

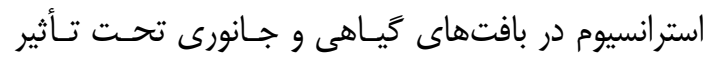

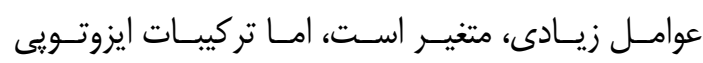

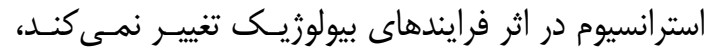

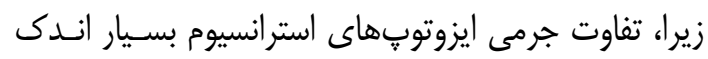

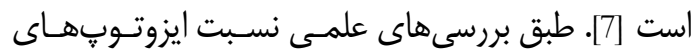

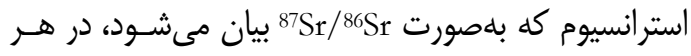

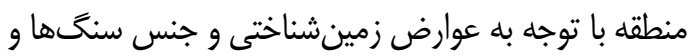

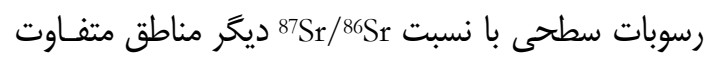

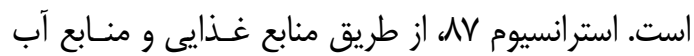

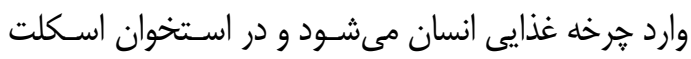

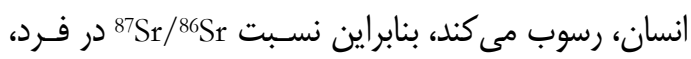
منعكس كننده نسبت منطقای است كه فرد در آن زندكى

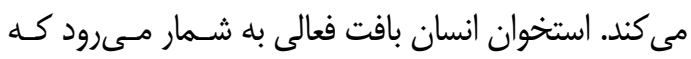

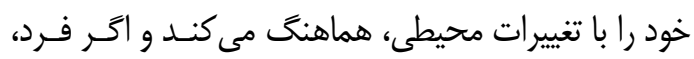

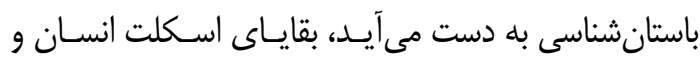

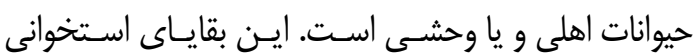

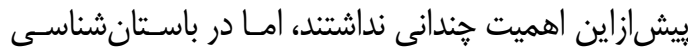

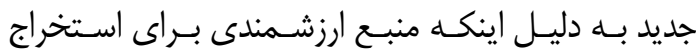

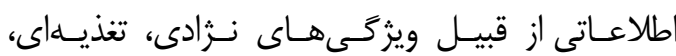
انسانشناسى و بيمارىهاى باستانى محسـوب مسىشـوند،

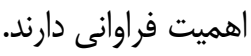
همخام با بيشرفت فناورى و رشد و كسترش مرزهاى

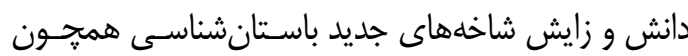

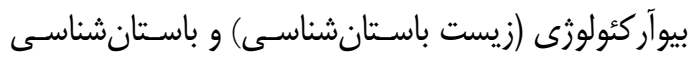
بيومولكولى، افقهاى جديدى در استخراج و مطالعة بئل بقاياى استخوانهاى باستانى انسان و جانوران يديدار شـــــاه

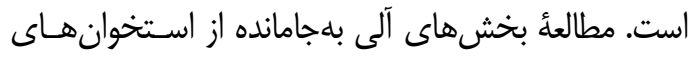
باستانى اطلاعات بارزشى در خصوص ويزگ هاى هاى زنتيكى

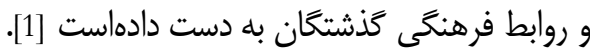

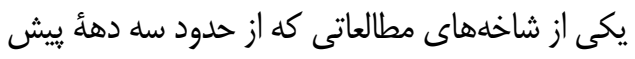
در مباحث باستانشناسى نوين ظهـور كرده اسـت، مطالعـأ ايزوتوبهاى پِيدار موجود در بقايـاى اسـتخوان و دنــان است. ايزوتوضهاى متعددى در تحقيقات باستانشناسى به

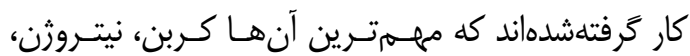

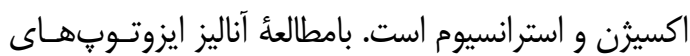

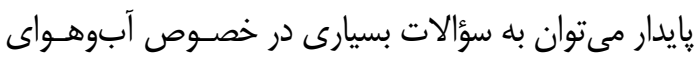
زمان باستان، تتذيه و اقتصاد زيستى و نيز جابهجـايىهـاو

مهاجرتهاى گروههاى انسانى كذشتنه، باسخ داد [2].

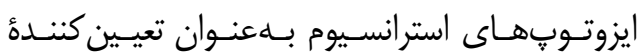

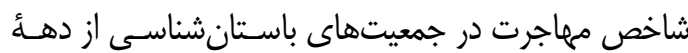

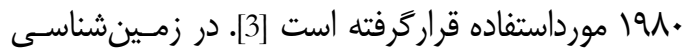

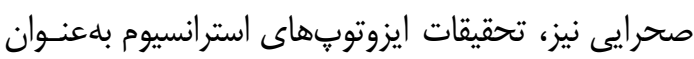

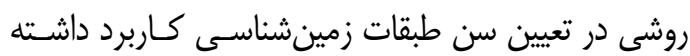

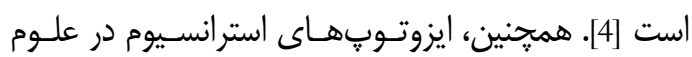
محيطزيست، براى مطالعه تأثيرات و وسعت مواد بـا منشـاً

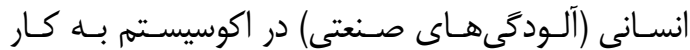

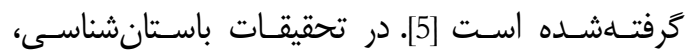

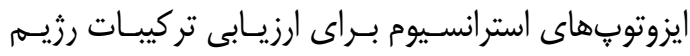




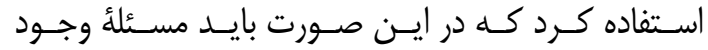

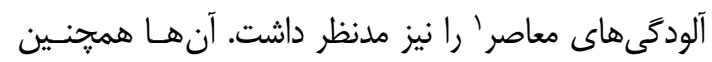

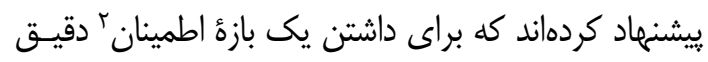

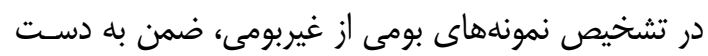

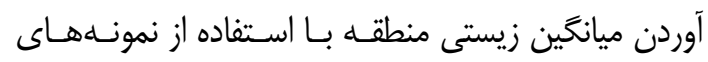

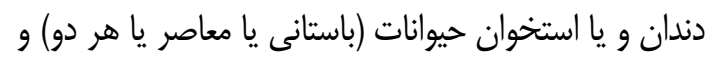

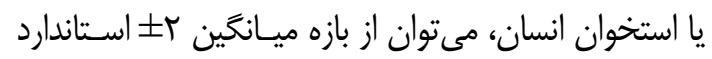

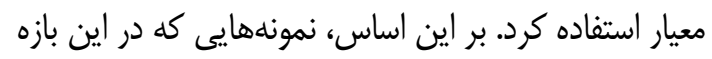

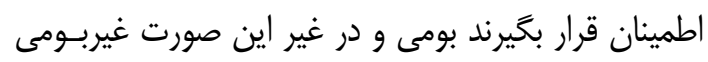

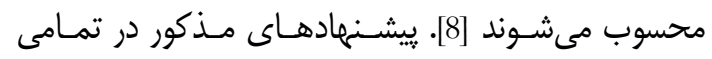

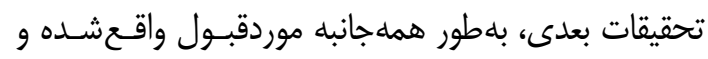

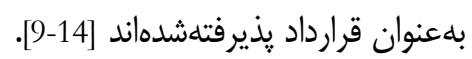
اين روش در محوطههاى باستانى متعددى به كار رفته

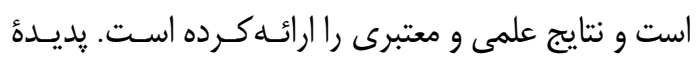

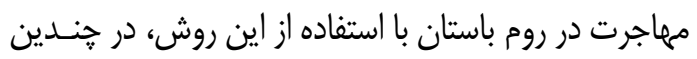

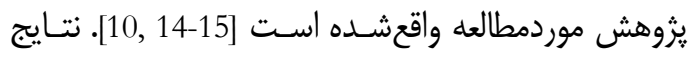
يكى از اين مطالعات نشان دادهاست كه درصـــ بـالايى از

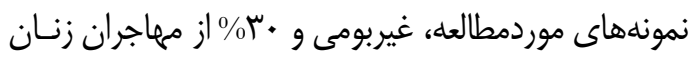

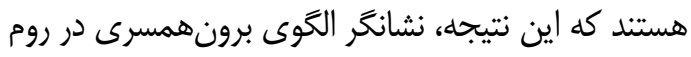

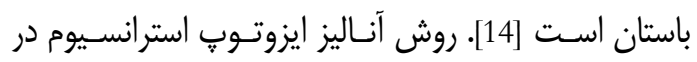
مطالعأ مهـاجرت در آمريكـاى جنـوبى نيـز مورداسـتفاده

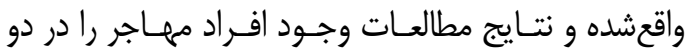

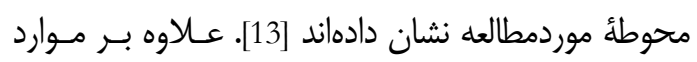

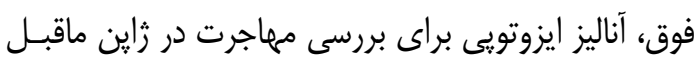

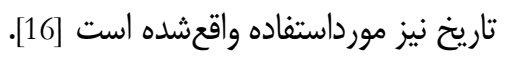
در ايران، تحقيقات ايزوتوبى بر نمونههاى باستانى در

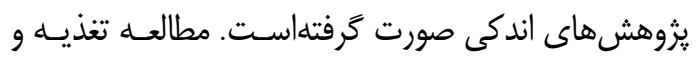

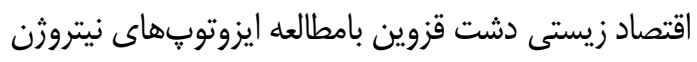

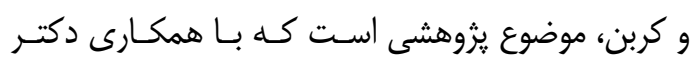

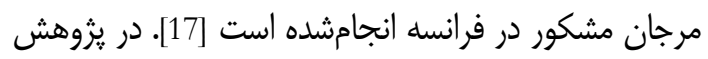

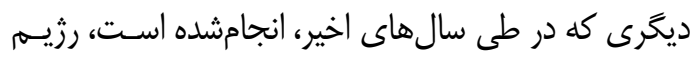

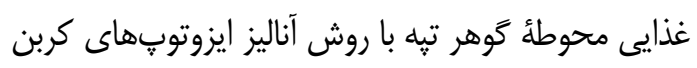

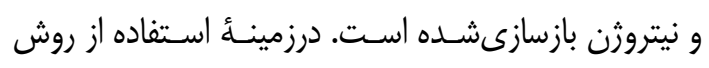

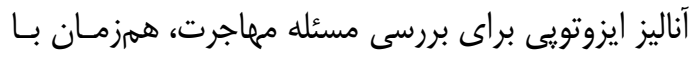
يثزوهش حاضر تحقيقات ديخرى در قالب پايان نامه دكتـرا

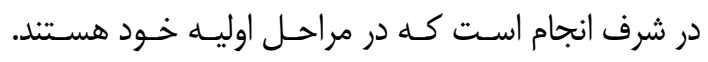
بلهور كلى مىتوان تفت كه غير از برخى تحقيقات بر روى احلى إنه

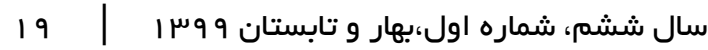

محيط زندگى خود را تغيير دهد نسبت

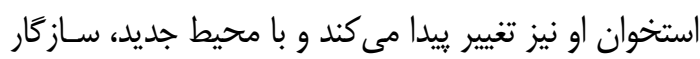

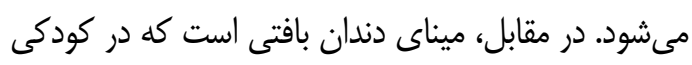

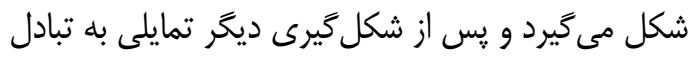

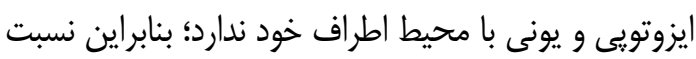

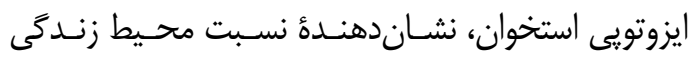

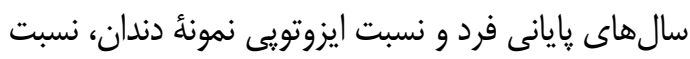

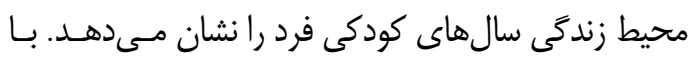

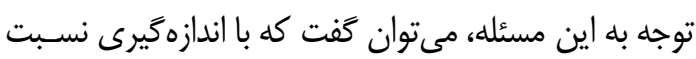

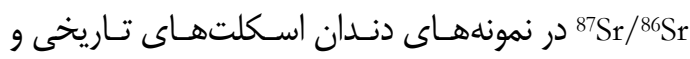
مقايسٔ آن با ميانكَين افراد يا اسكلتهاى همان محوطه موردمطالعه (بـهـعنــوان

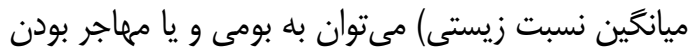
نمونه اسكلتهاى موردمطالعه، يى برد [8]

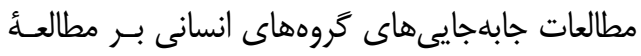

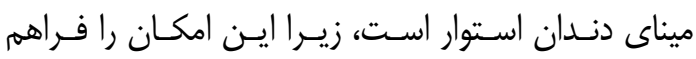

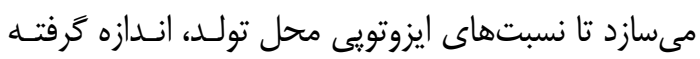

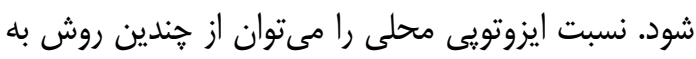

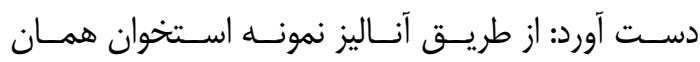

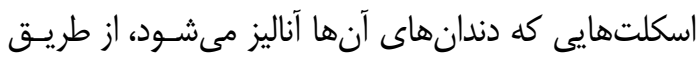

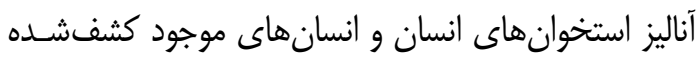

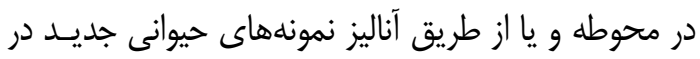

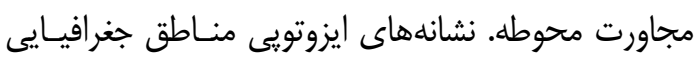

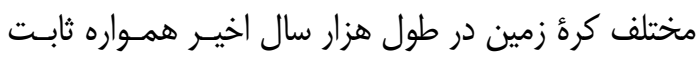

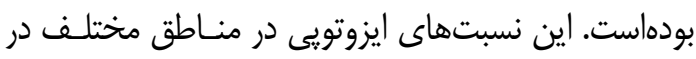

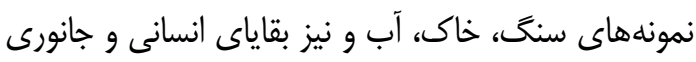

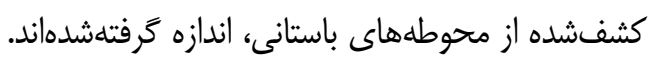
براى به دست آوردن مقياسى در تشخيص نمونهائهاى بازي

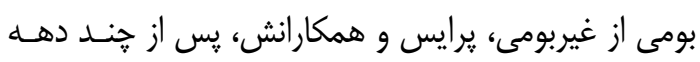

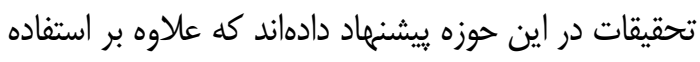

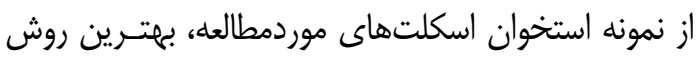
براى تخمين نسبت ايزوتوبى زيستى محوطههاى باستانى

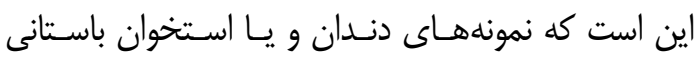

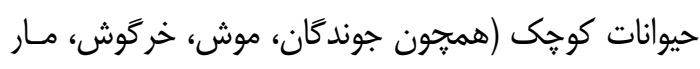

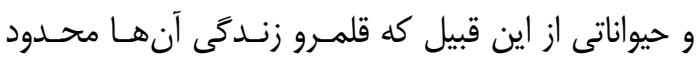
است) اندازمخيرى شوند. در صـورت نبــود ايسن نمونسهـــا،

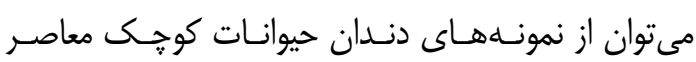


(UTM:0508825-4072870)

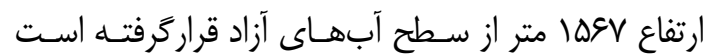

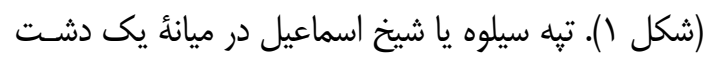

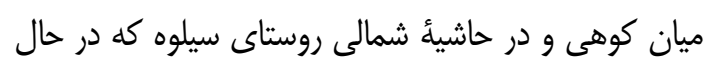

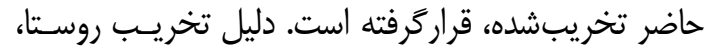

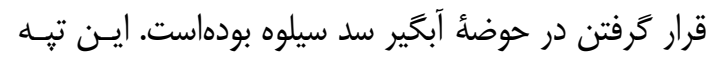

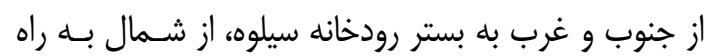

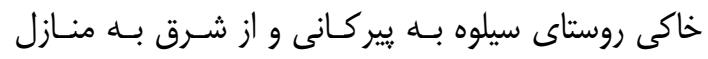

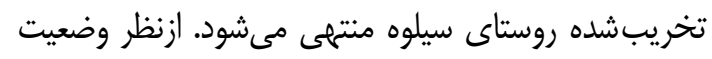

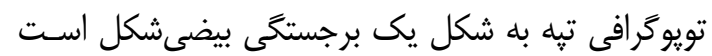

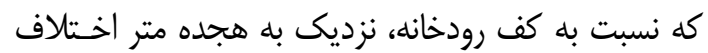

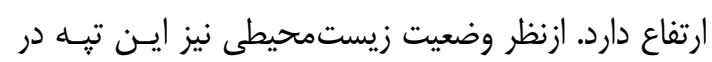

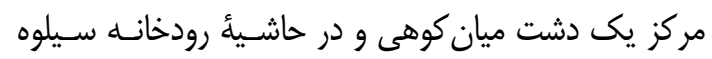

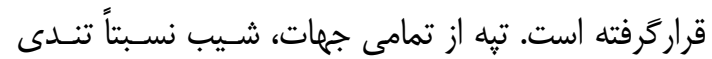

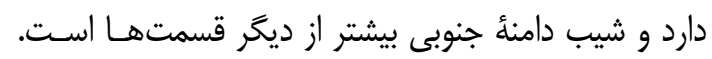
در شرق و غرب برجستخى اصلى، دو سطح تقريباً مسـطـح

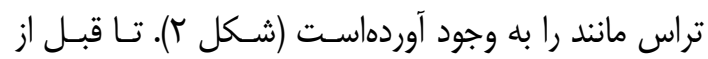

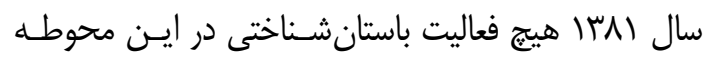

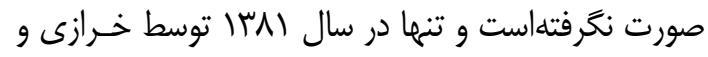

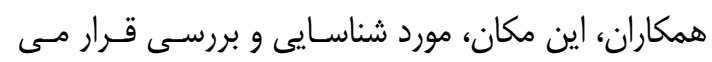

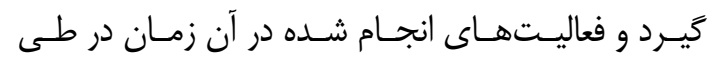

نسبتهاى ايزوتويى نمونههـاى سـنَّ كـه توسـط زمـين

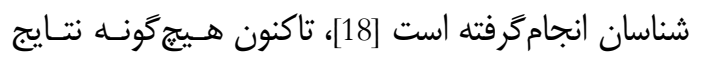

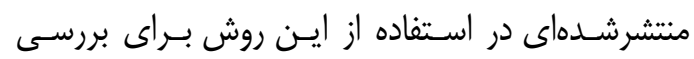
مهاجرتهاى باستانى ايران موجود نيست.

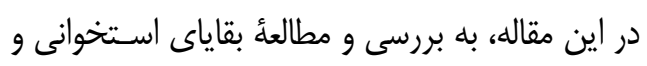

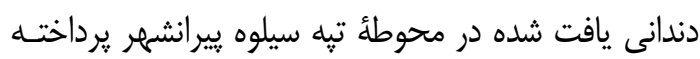

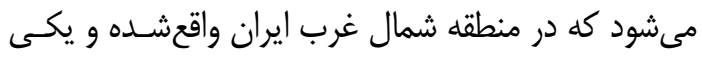

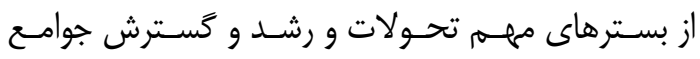

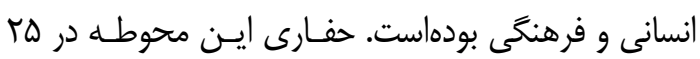

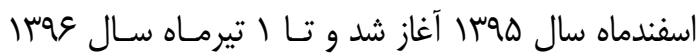

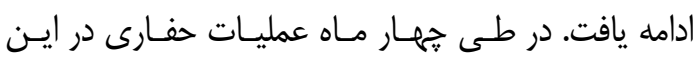

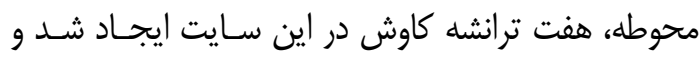

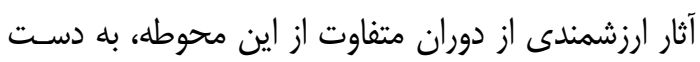

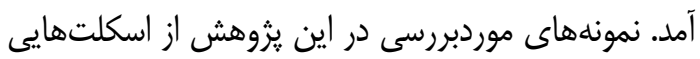

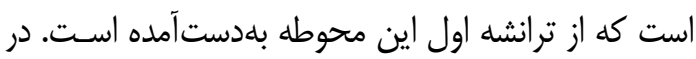

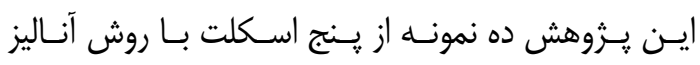

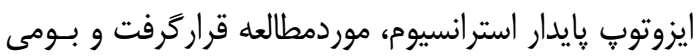
يا مهاجر بودن نمونه اسكلتها بررسى شد.

\section{ז. معرفى تبه سيلوه يير انثهر}

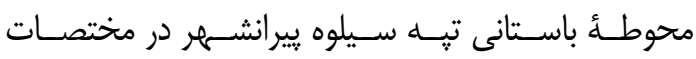

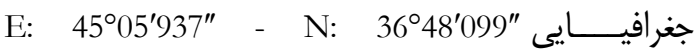

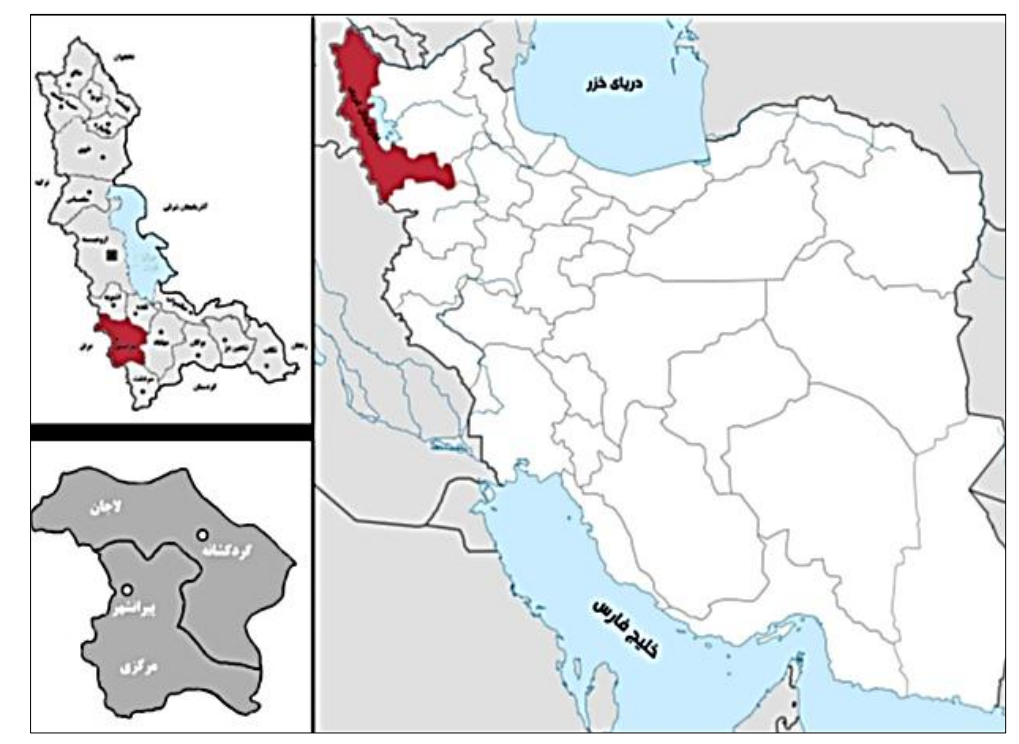

شكل ا: موقعيت جغرافيايى شهرستان بيرانشهر و سد سيلوه و محوطه تبه سيلوه در شمال غرب ايران

Fig. 1: Geographical location of Tepe Silveh and Piranshahr, North-Western Iran 


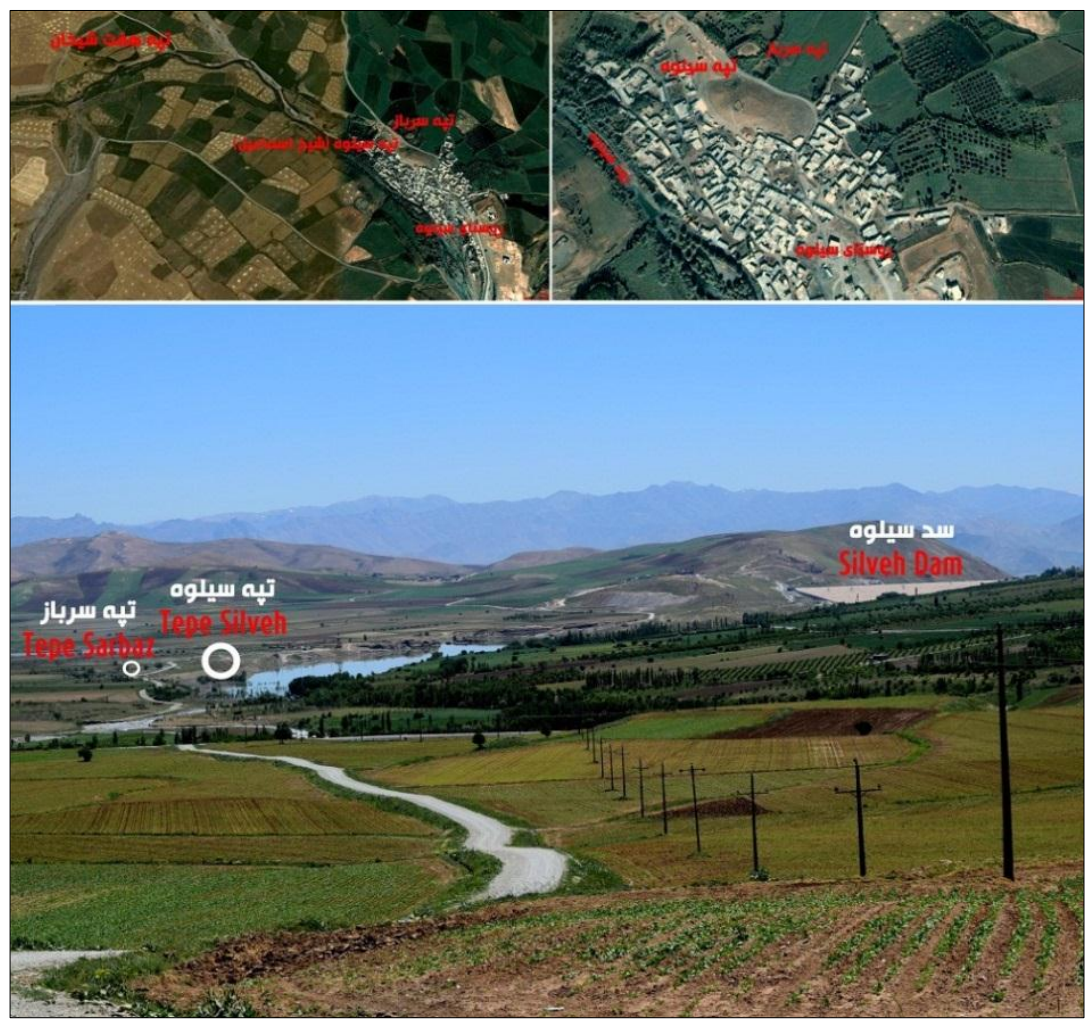

شكل r: تصاويرى از موقعيت قرارگيرى سد سيلوه و محوطههاى تِه سيلوه، تِه سرباز و هفت شيخان Fig. 2: Photos of the Silveh dam, Tepe Sarbaz and Haft Shikhan locations

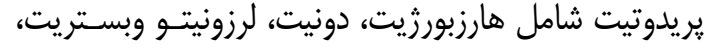

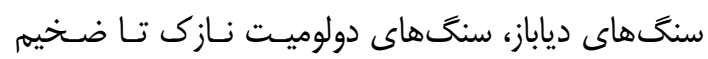

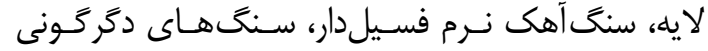

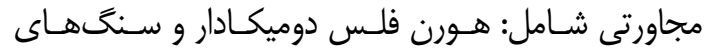

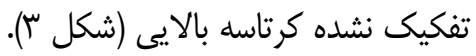

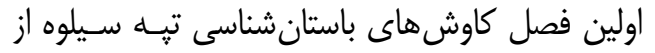

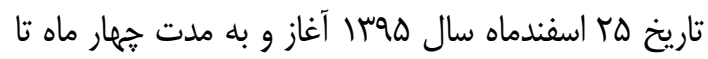

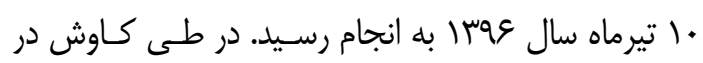

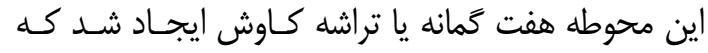

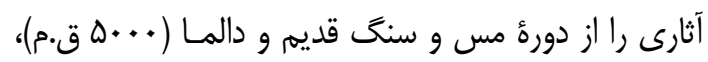

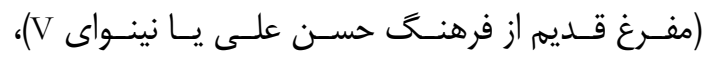

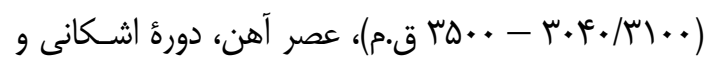

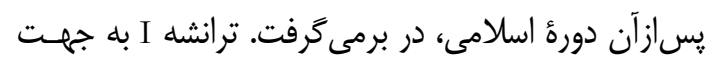

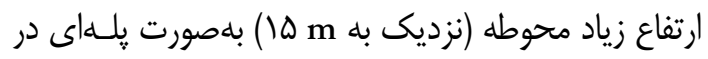

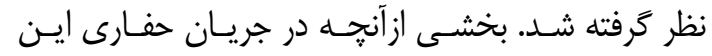

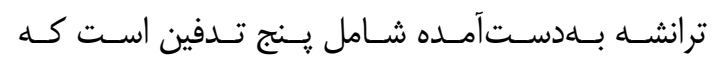

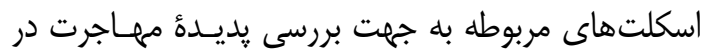
اين يزوهش موردبررسى قرار كرفتند.
نزديك به جهار ماه، شروع اولين فعاليتهاى علمى كاوش در اين محوطه بودهاست.

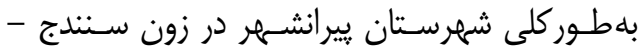

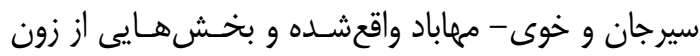

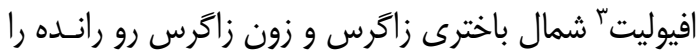

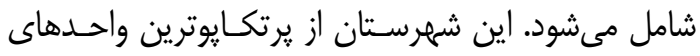
زمين ساختى ايران است كه سبب فعاليت دَّرَّونى بسـيار

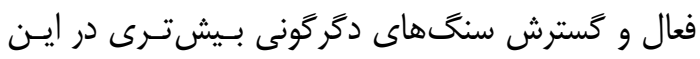

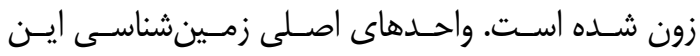

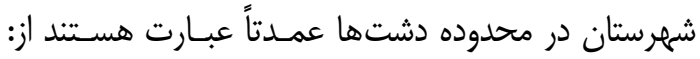

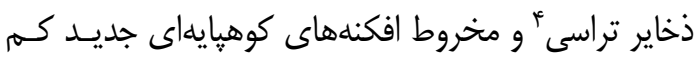

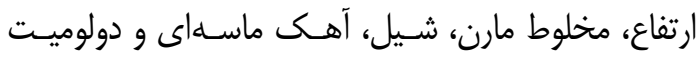
ماسهاى. در ساير مناطق شهرستان، واحدهاى سنگَبسـتر

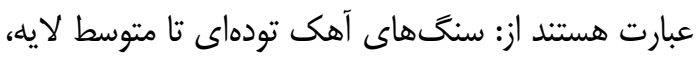

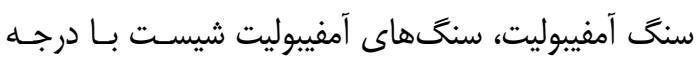

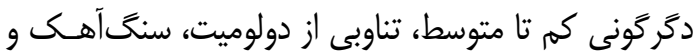

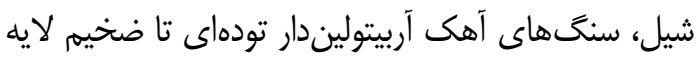

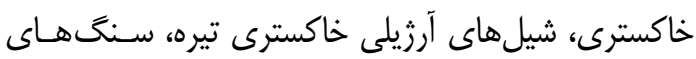

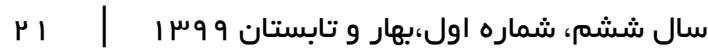




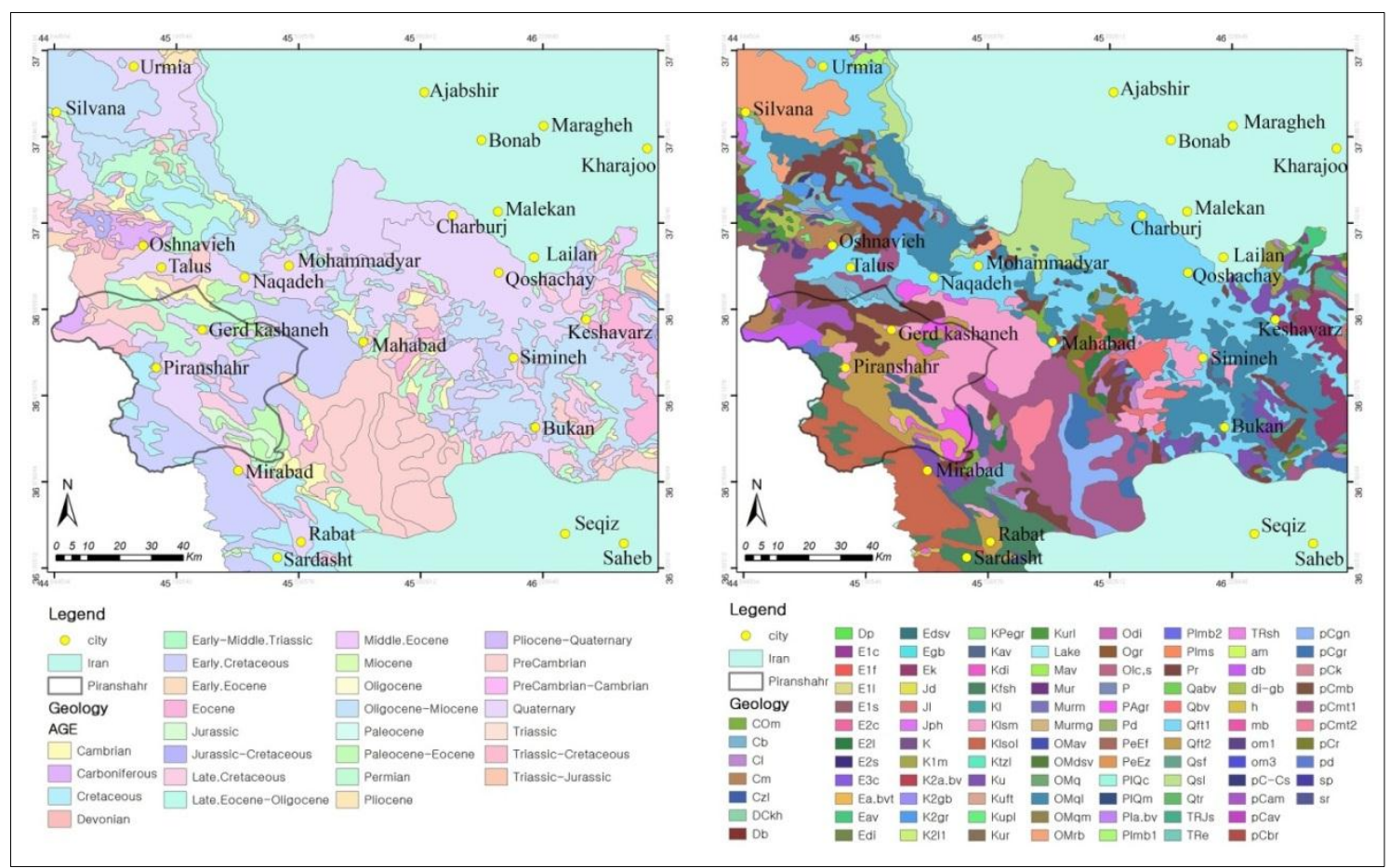

شكل سا: ساختار زمينشناسى شهرستان ييرانشهر

Fig. 3: Geological map of Piranshahr city and the adjacent regions

قابلمشاهده است؛ بنابراين نمونههاى استخوانى همخى از

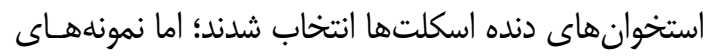

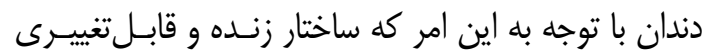

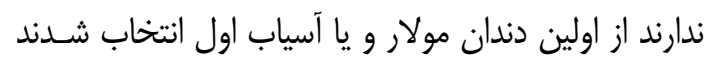

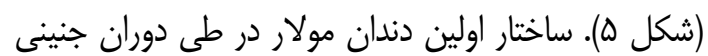

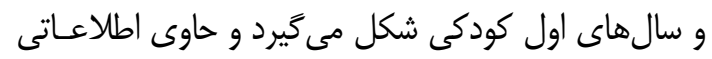
از ازين دوران است [19].

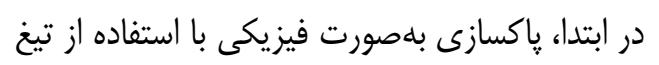

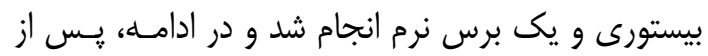

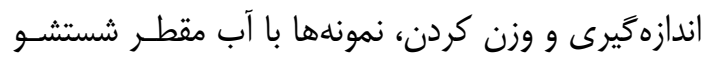
داده شدند (با توجه به اين امر كه براى حفن حفاظت اسكلتها

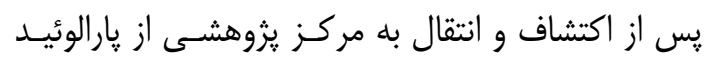

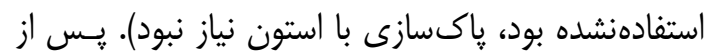

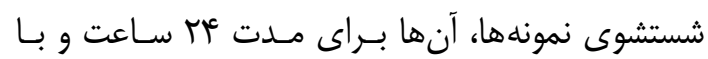

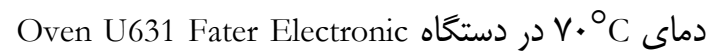

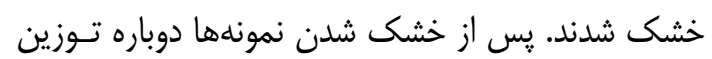

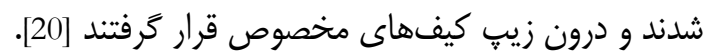

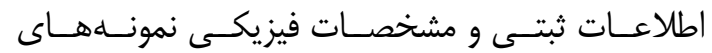

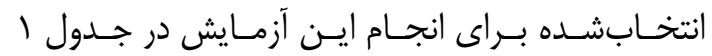

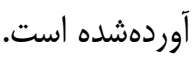

\section{"- معرفى نمونههاى موردمطالعه}

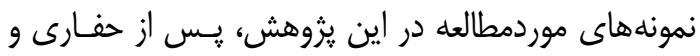

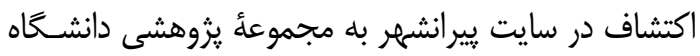

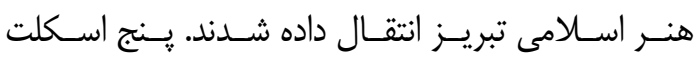

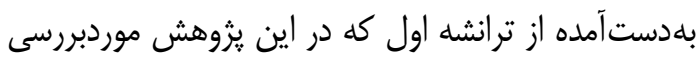

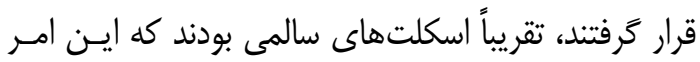

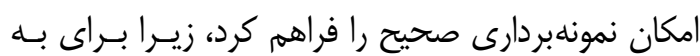

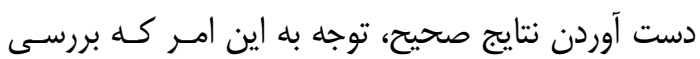
آناليزى و عنصرى كدام استخوان از اسكلت با كدام دندان إندان

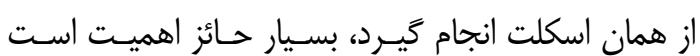

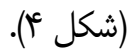
با توجه به اكثر يزوهشهاى انجامشده در اين حـوزه،

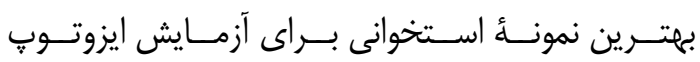

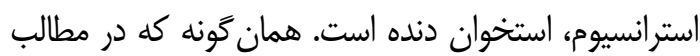

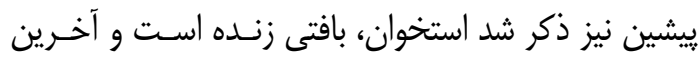

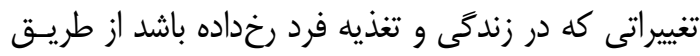

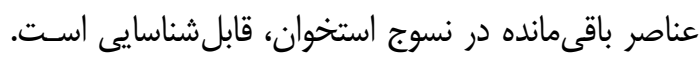
بر اساس آزمايشها، استخوان دنده در بين استخوانهـائ

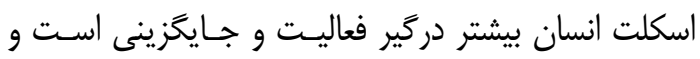

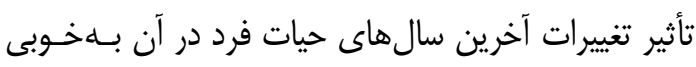

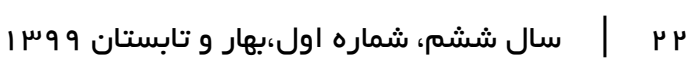




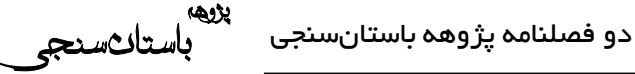
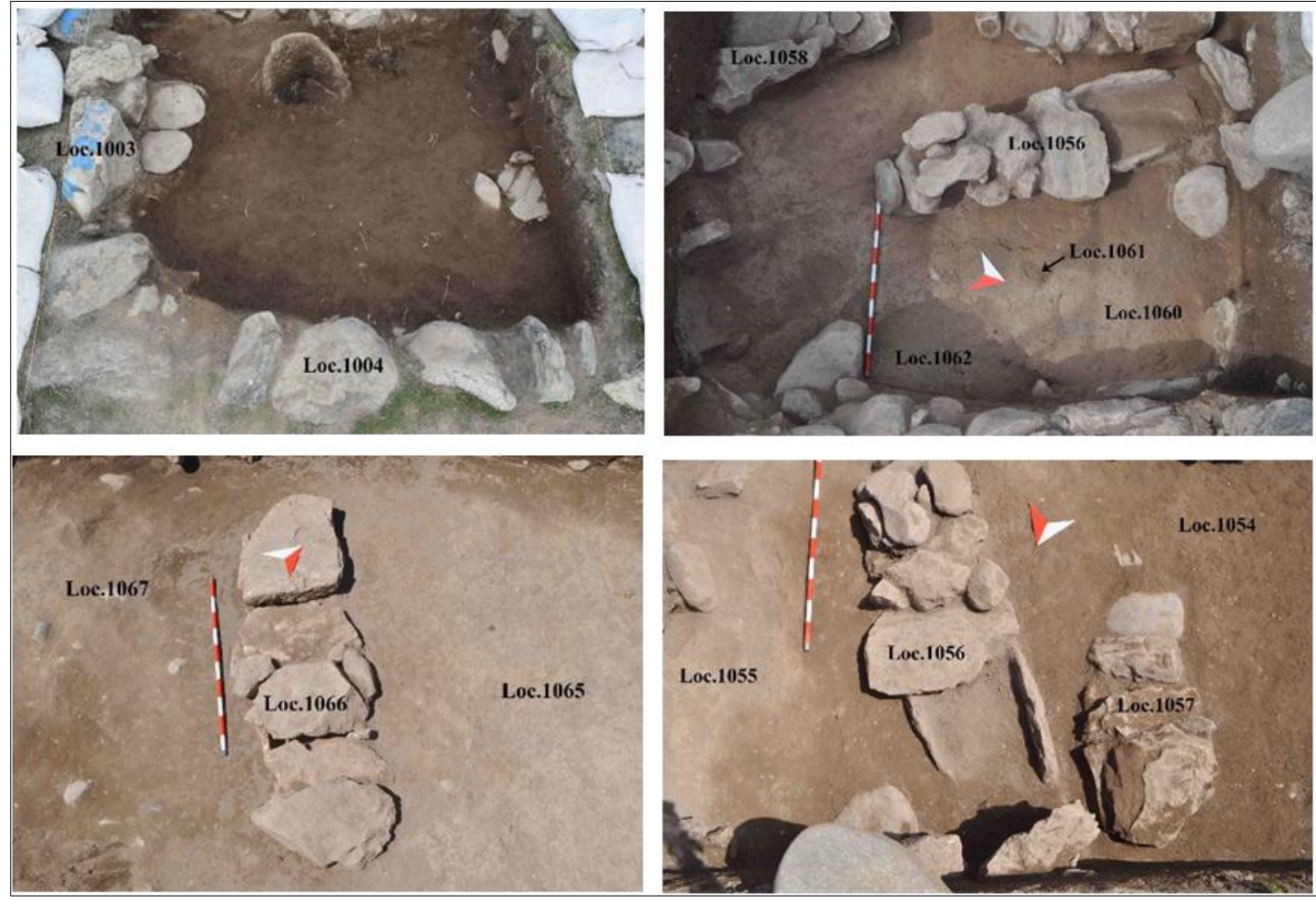

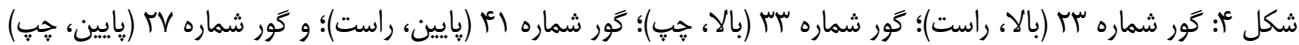
Fig. 4: (up-right) Grave no. 23; (up-left) Grave no. 33; (down-right) Grave no. 41; (down-left) Grave no. 27
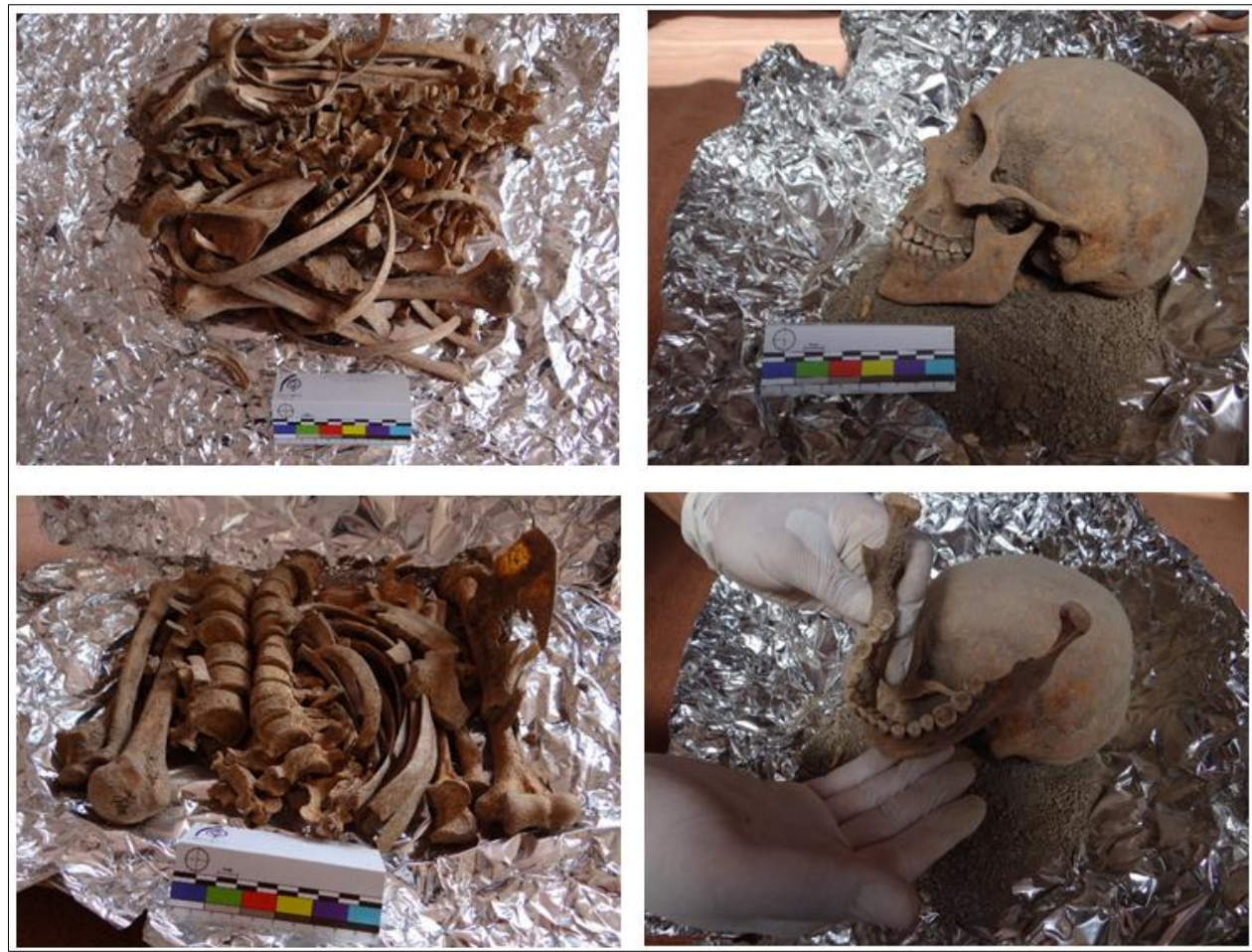

شكل ه: اسكلت اول (بالا)، اسكلت دوم (يابين)

Fig. 5: (up) first skeleton; (down) second skeleton 
جدول (: مشخصات نمونههاى موردمطالعه از اسكلتهاى محوطه تيه سيلوه

Table 1: Characteristics of the samples from Tepe Silveh skeletons

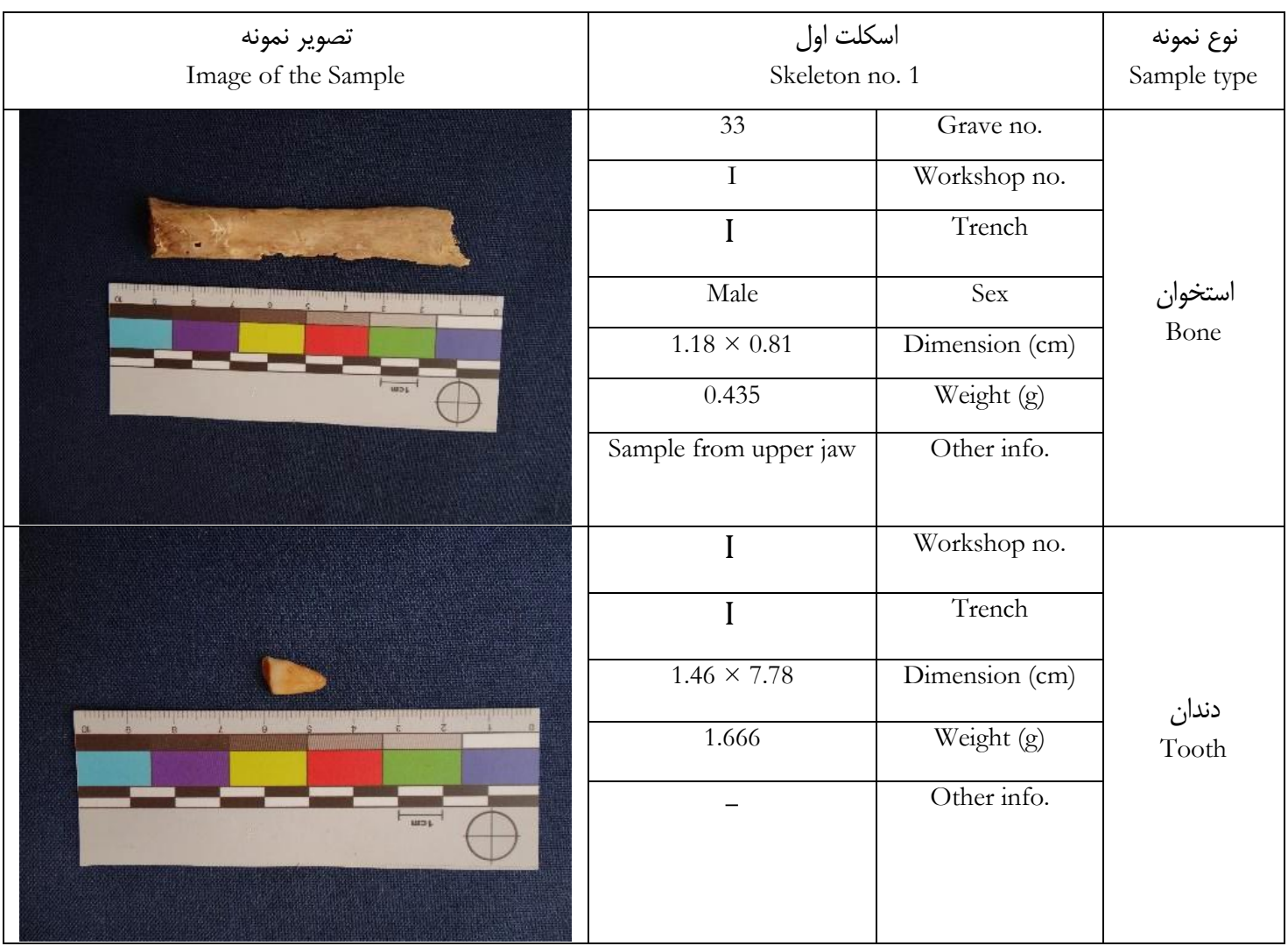

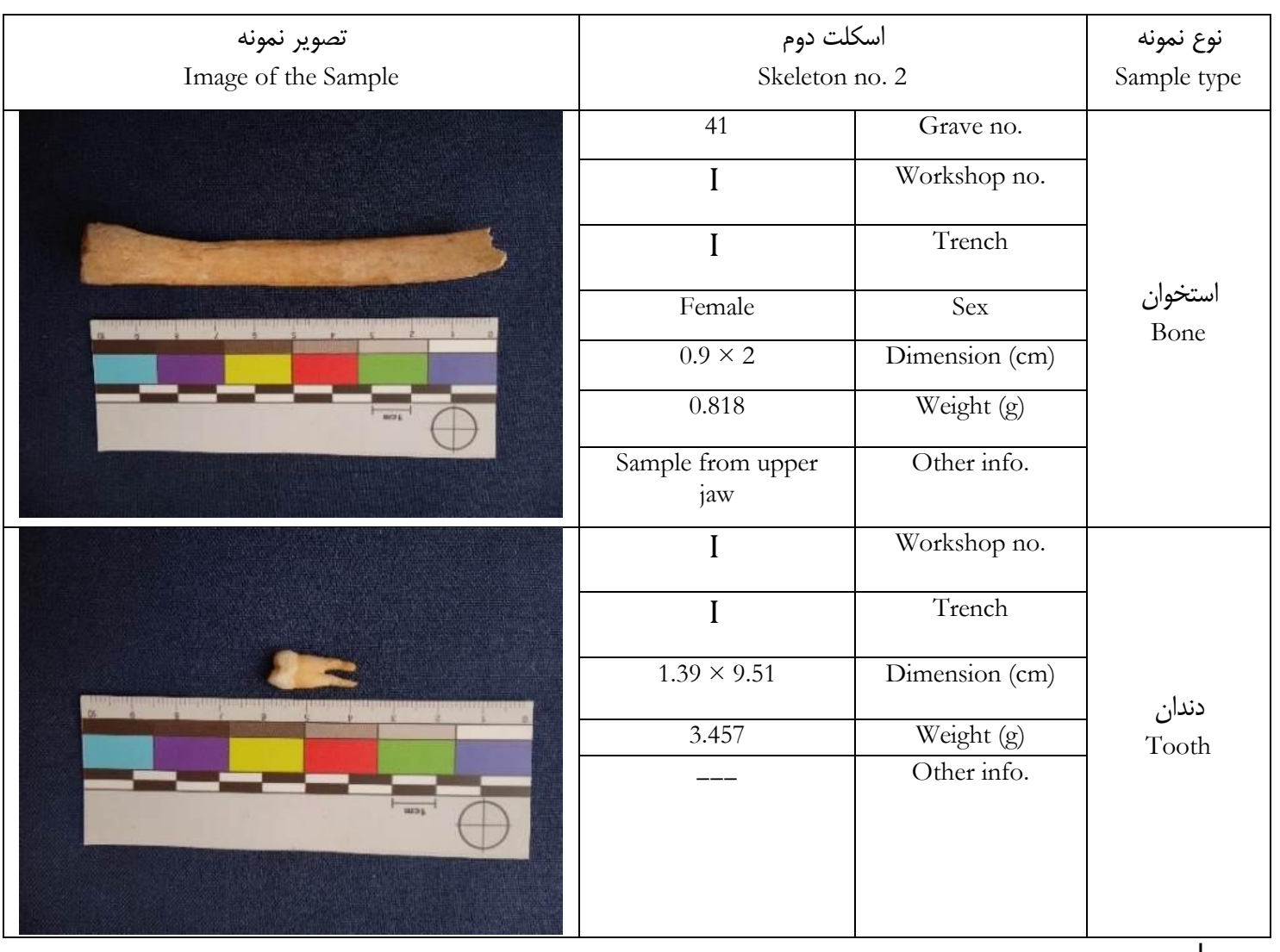

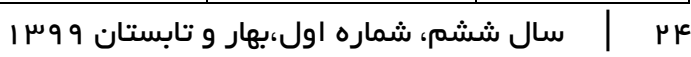


ادامه جدول 1:Continue

Table 1: Continued

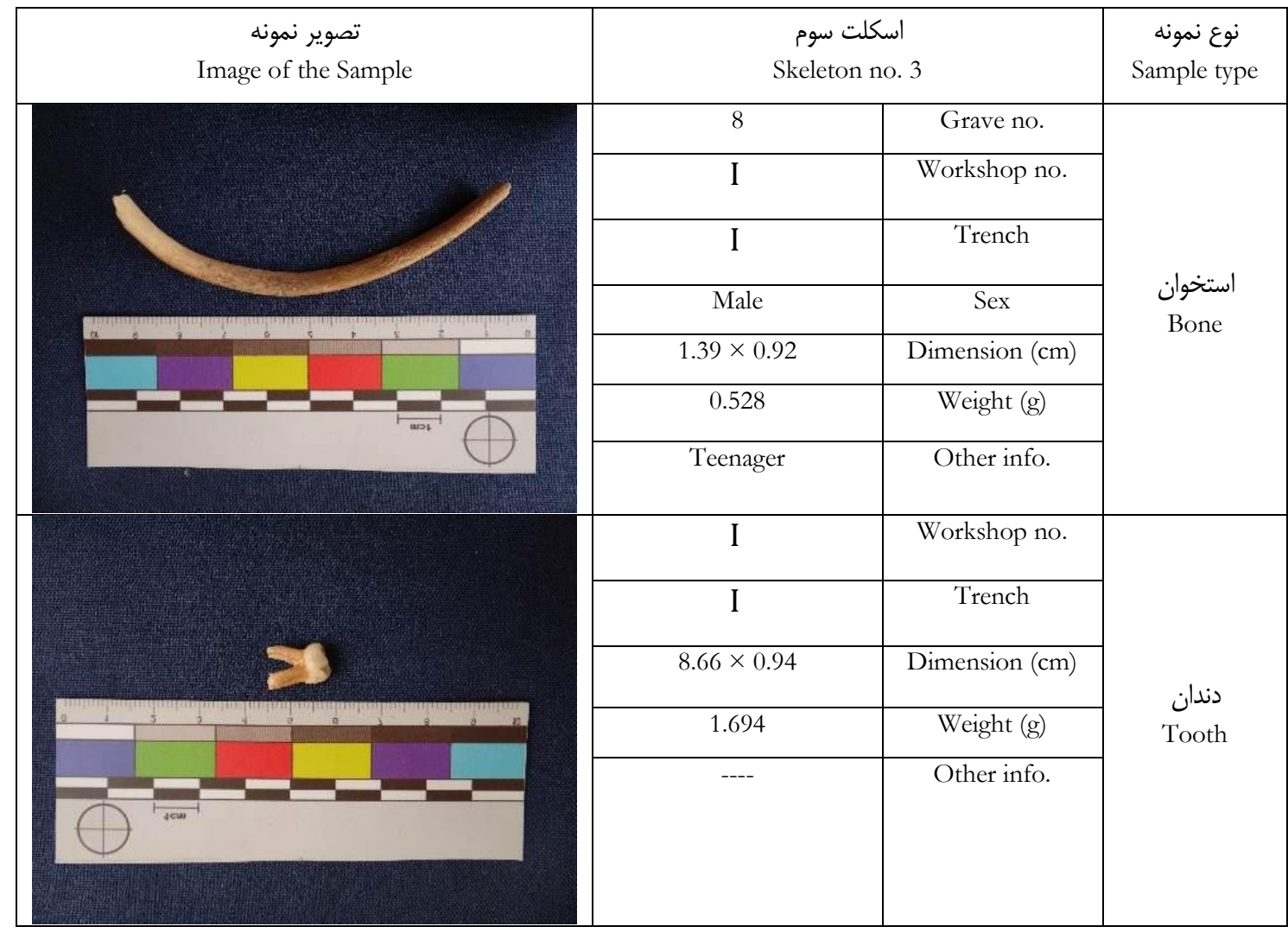

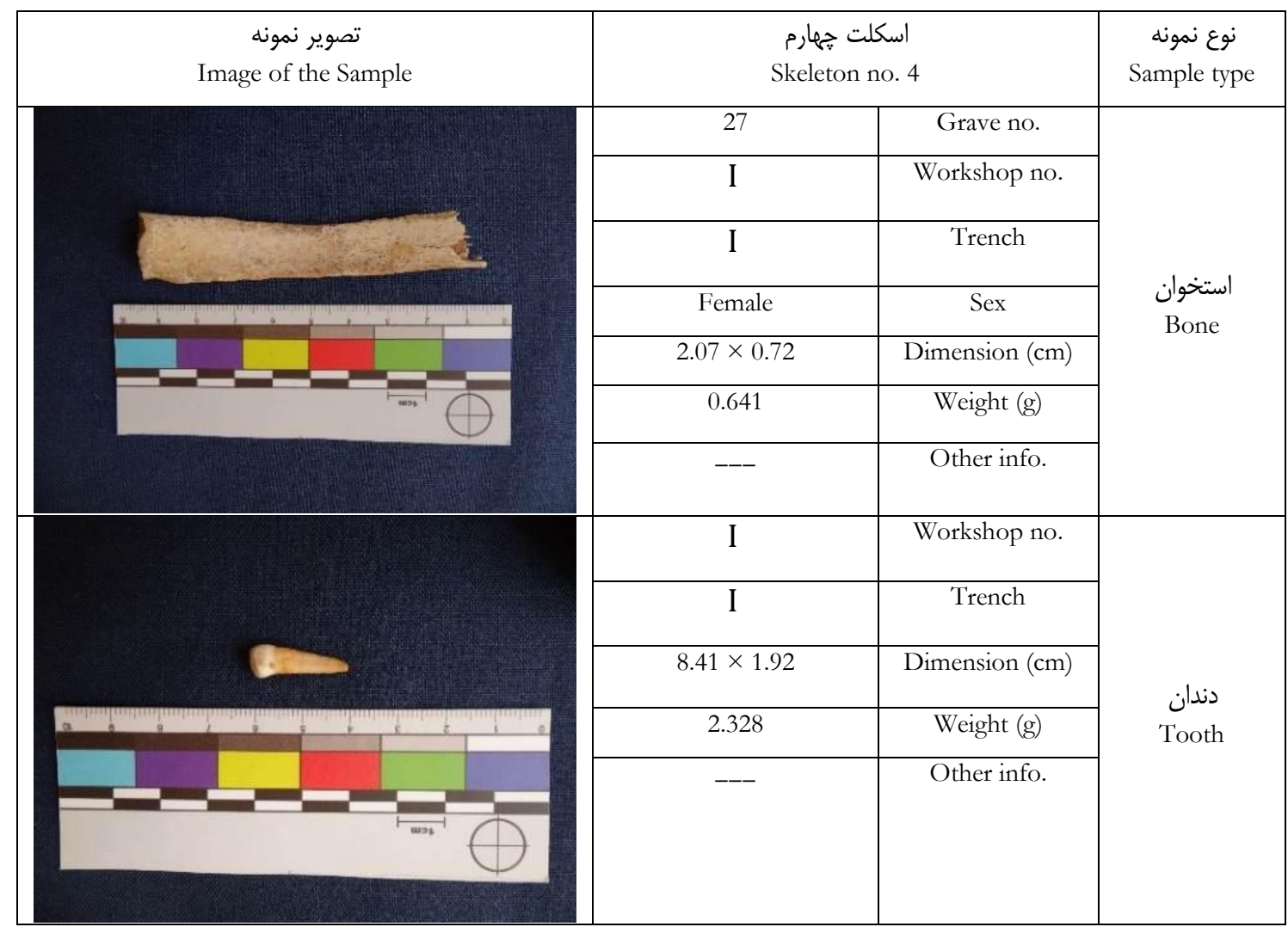

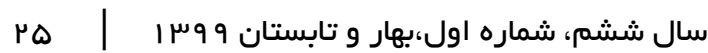




\begin{tabular}{|c|c|c|c|}
\hline \multirow[t]{8}{*}{$\begin{array}{c}\text { تصوير نمونه } \\
\text { Image of the Sample }\end{array}$} & \multicolumn{2}{|c|}{$\begin{array}{l}\text { اسكلت ينجم } 5 \text { Skeleton no. } 5 \\
\text { Sk }\end{array}$} & $\begin{array}{c}\text { نوع نمونه } \\
\text { Sample type }\end{array}$ \\
\hline & 23 & Grave no. & \multirow{7}{*}{$\begin{array}{l}\text { استخوان } \\
\text { Bone }\end{array}$} \\
\hline & I & Workshop no. & \\
\hline & I & Trench & \\
\hline & Male & Sex & \\
\hline & $2.15 \times 0.7$ & Dimension $(\mathrm{cm})$ & \\
\hline & 0.722 & Weight (g) & \\
\hline & -- & Other info. & \\
\hline & I & Workshop no. & \multirow{5}{*}{$\begin{array}{l}\text { دندان } \\
\text { Tooth }\end{array}$} \\
\hline & I & Trench & \\
\hline & $11.6 \times 1.7$ & Dimension $(\mathrm{cm})$ & \\
\hline & 4.830 & Weight (g) & \\
\hline & --- & Other info. & \\
\hline
\end{tabular}

خالص كذاشته و بله مدت r دقيقه در حمـام اولتراسـونيك

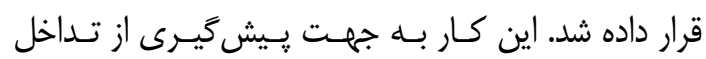

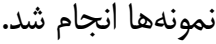

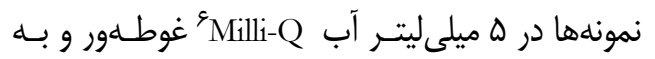
مدت r دقيقه در حمام اولتراسونيك قرار داده شدند. آب و آلودخى هايى كه در طول آمادهسـازى از استخوان و مينـا

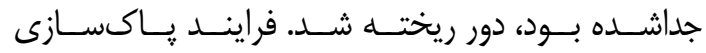

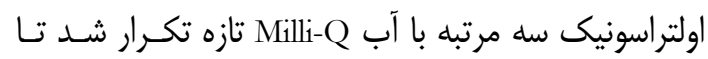
هر گَونه آلودگى از نمونهها جدا شود. هر كدام از نمونهها در

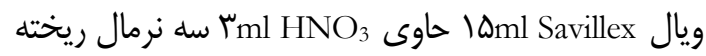
شد و به مدت ع دقيقه كذاشـته مسىشـود تـا استرانسـيوم ثانويه ناشـى از لايـهـهـاى بيرونس شسـته و زدوده شـود.

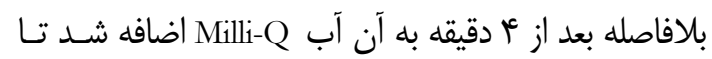

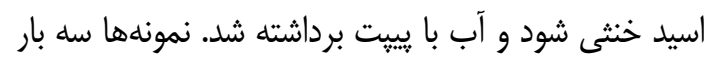
در آب Milli-Q شسـته و خشـك شــند. شدن، مجدداً در

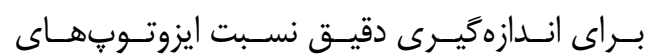
استرانسيوم با دستخاه ICP-MS لازم است كه استرانسيوم،

\section{ع. دستخاههاى مورداستفاده و روش انجام \\ آزمايشها داسناهن}

دندان دائمى آسياب اول هم به لحاظ استحكام و هـــم بــه لحاظ اين كه در دوران جنينى شروع به شكل

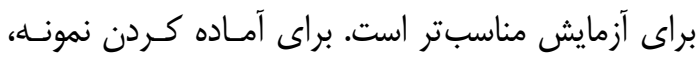

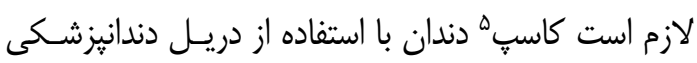

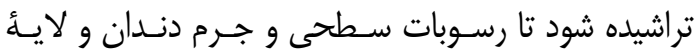
بيرونى مينا كه ممكن است حاوى آلودگى ناشى از ديـارنز

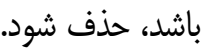
نمونـهـهــاى مينــا و اسـتخوان بــا اسـتفاده از دريـلـ دندانيزشكى Crown ساخت كشور هين و با يكتقلم (سـر

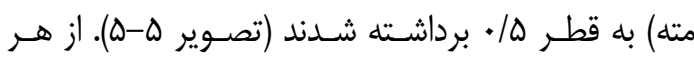
نمونه، به ميزان حدود •م تا •و ميلى

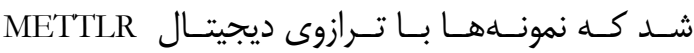
TOLEDO

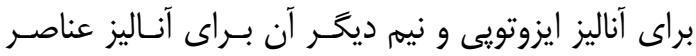

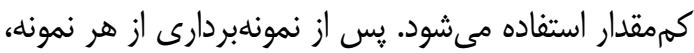

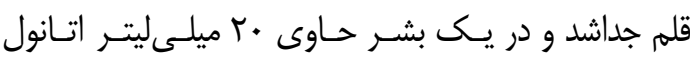

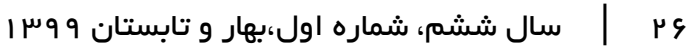


استرانسيوم نمىشوند و رزين، استرانسيوم را نغاه مسىدارد.

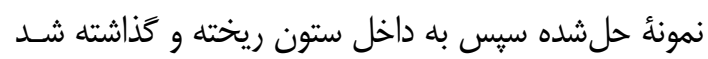

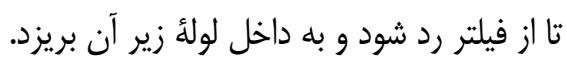

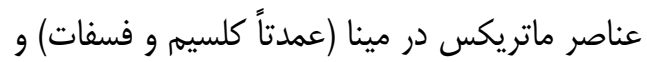

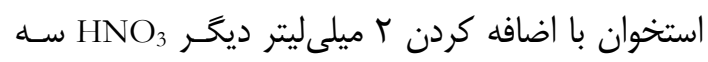

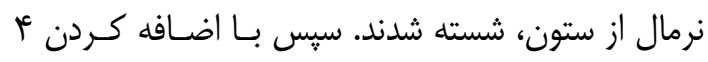

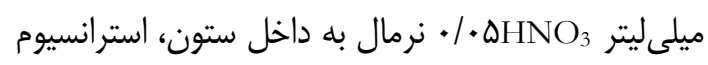

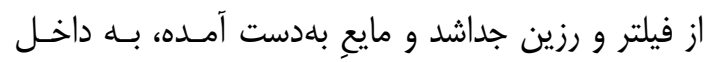

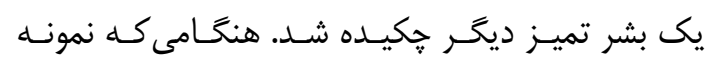

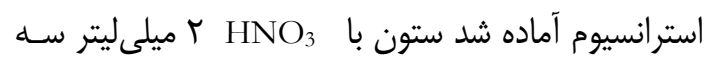

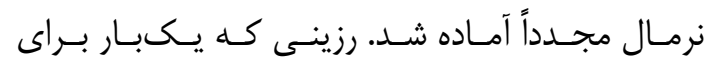

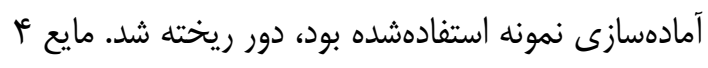

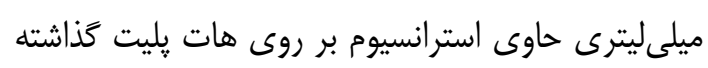

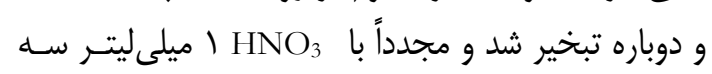

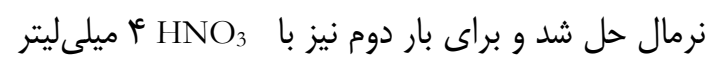

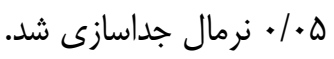
آناليز ايزوتويى نمونههاى دندان و استخوان بان با استفاده

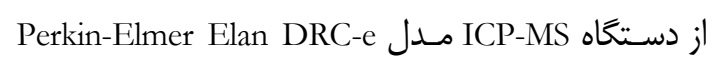

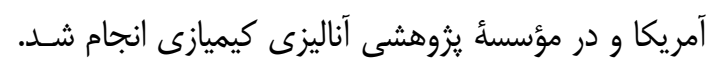

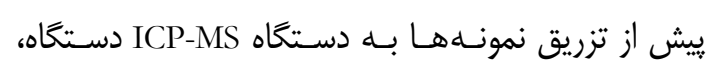

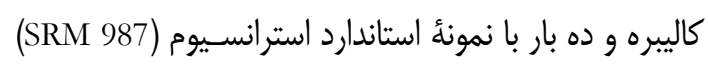

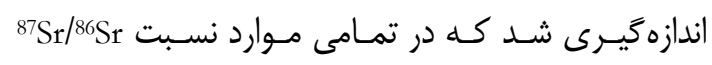

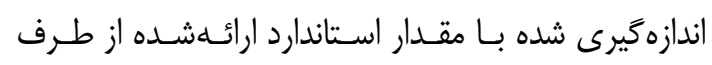
شر كت سازنده، مطابقت داشت.

\section{ه. نتايج و بحث}

براى تشخيص اسكلتهاى بومى از غيربومى، ييش از هر

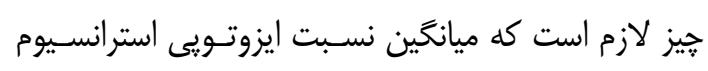

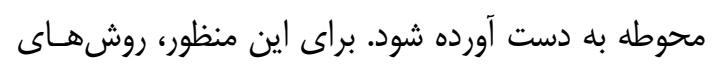

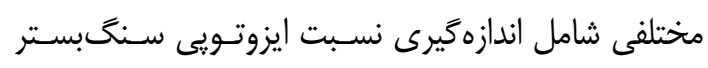

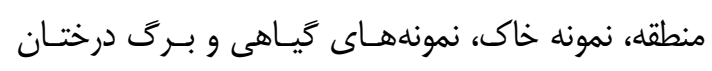

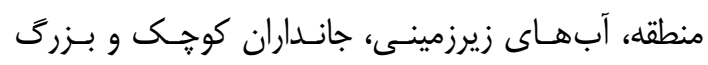

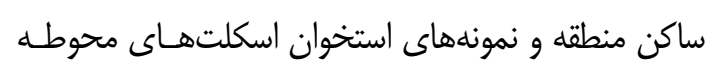

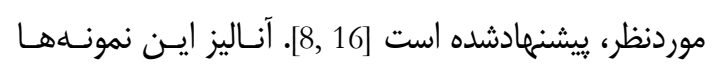

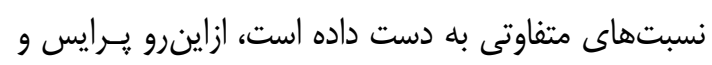

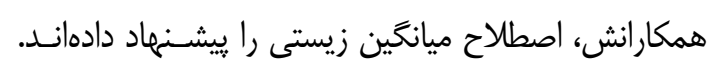

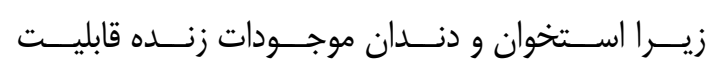

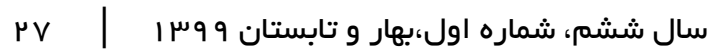

خالصسازى و يا جداسازى شود. دليل اين كار ايـن اسـت

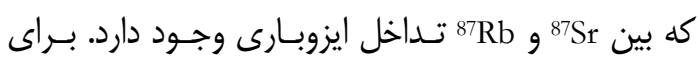

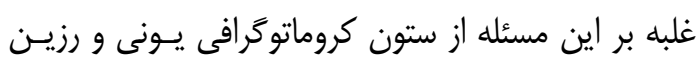

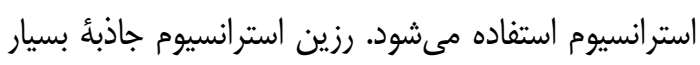
زيادى نسـبت بـهـ استرانسـيوم دارد كـه درنتيجـهـ امكـان

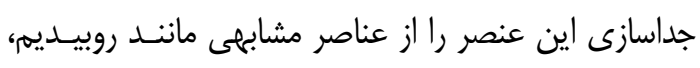
كلسيه، باريم و ديخر عناصر، فراهم مسى آورد [21]. مقــــار

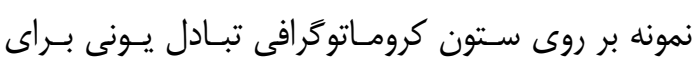

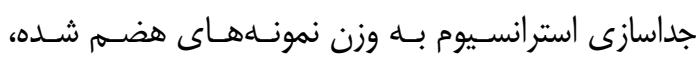

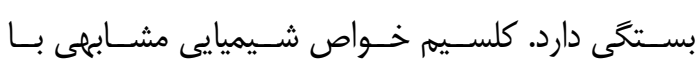

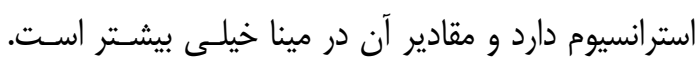

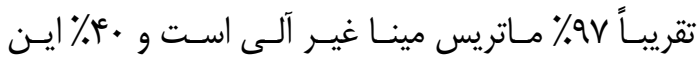

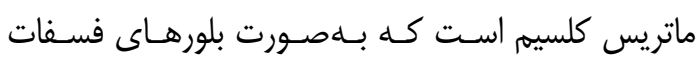

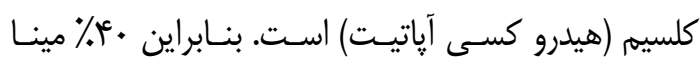

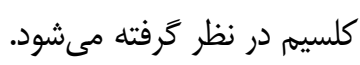

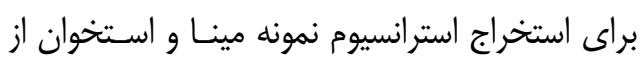

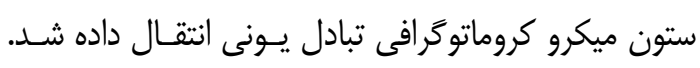

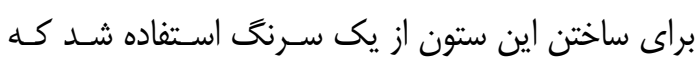

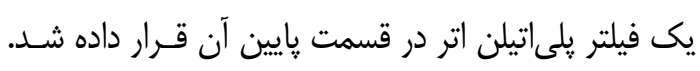
رزين استرانسيوم مورداستفاده در اين يزوهش، -SR-B100

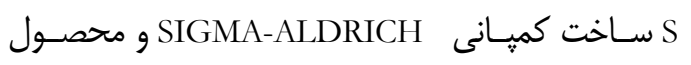
كشور آمريكا است.

18-Crown- د د

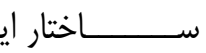
4'4'(5')-di(tert-butylcyclohexano6 Sr(NO $\left.\mathrm{N}_{3}\right)_{2}\left(\mathrm{DtBuCH}_{18} \mathrm{C}_{6}\right)$

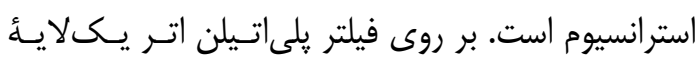

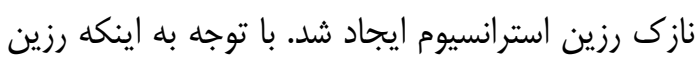

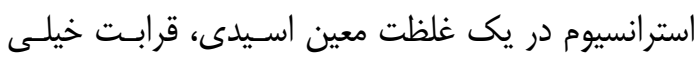

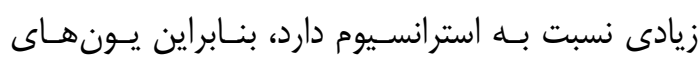

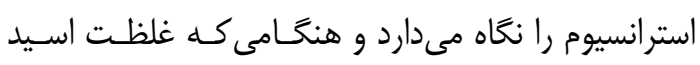

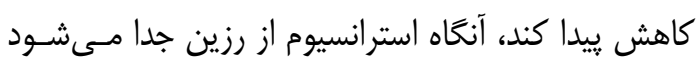

لايئ نازكى از رزين بر روى سـتون (سـرنحى) حـاوى

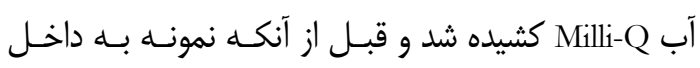

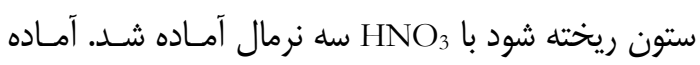

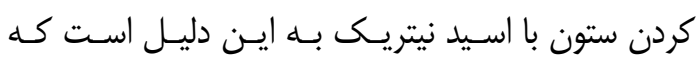

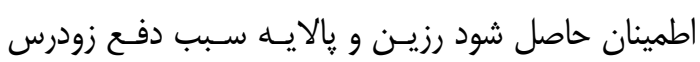


جدول سا: ميانگ̌ن مقادير

$$
\text { معيار اندازمخيرى }
$$

Table 3: The mean and mean $\pm 2 S D$ of strontium ratios of the bone samples

\begin{tabular}{|c|c|}
\hline Mean ratio & 0.8076 \\
\hline SD & 0.0057 \\
\hline Mean+2SD & 0.8190 \\
\hline Mean-2SD & 0.7692 \\
\hline
\end{tabular}

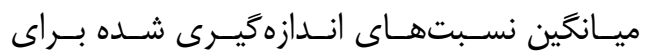

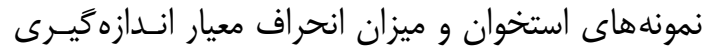

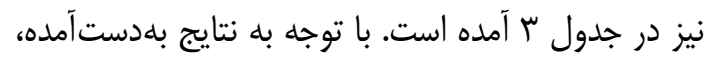

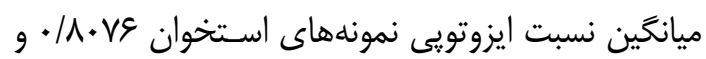
انحر اف معيار آن هV ه • + • است.

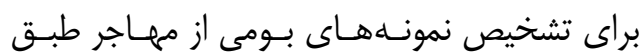

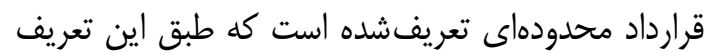

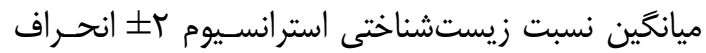

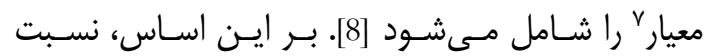

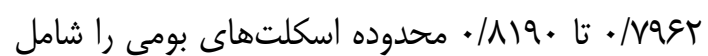
مىشود، به اين معنا كه نمونههـاى دنــانى كـهـ در ايـن محدوده قرار بخيرند، مربوط به اسكلتهاى بومى هستند

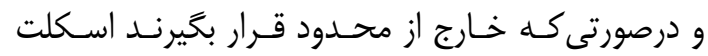
مربوطه غيربومى محسوب مىشوند. اين مقادير در شكل

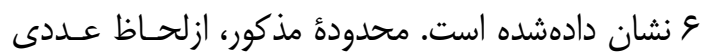

ميانگين گيرى قابلتوجهى دارند [8].

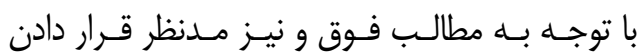

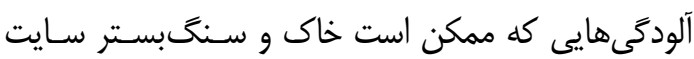

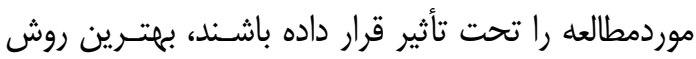

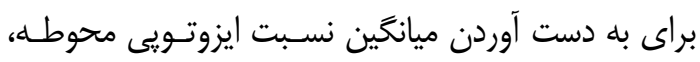

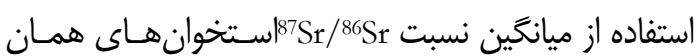
محوطه است. جدول r مقادير نسبت ايزوتويى استرانسيوم

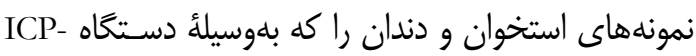
اندازهگيرى شدهاند، نشان مى دهد.

جدول r: مقادير Sr/86Sr AV در استخوان و دندان Table 2: The ${ }^{87} \mathrm{Sr} /{ }^{86} \mathrm{Sr}$ ratios of the bone and tooth samples

\begin{tabular}{|c|c|}
\hline Sample & ${ }^{87} \mathrm{Sr} / 86 \mathrm{Sr}$ \\
\hline Tooth no. 1 & 0.820 \\
\hline Tooth no. 2 & 0.795 \\
\hline Tooth no. 3 & 0.841 \\
\hline Tooth no. 4 & 0.823 \\
\hline Tooth no. 5 & 0.820 \\
\hline Bone no. 1 & 0.811 \\
\hline Bone no. 2 & 0.802 \\
\hline Bone no. 3 & 0.814 \\
\hline Bone no. 4 & 0.810 \\
\hline Bone no. 5 & 0.801 \\
\hline
\end{tabular}

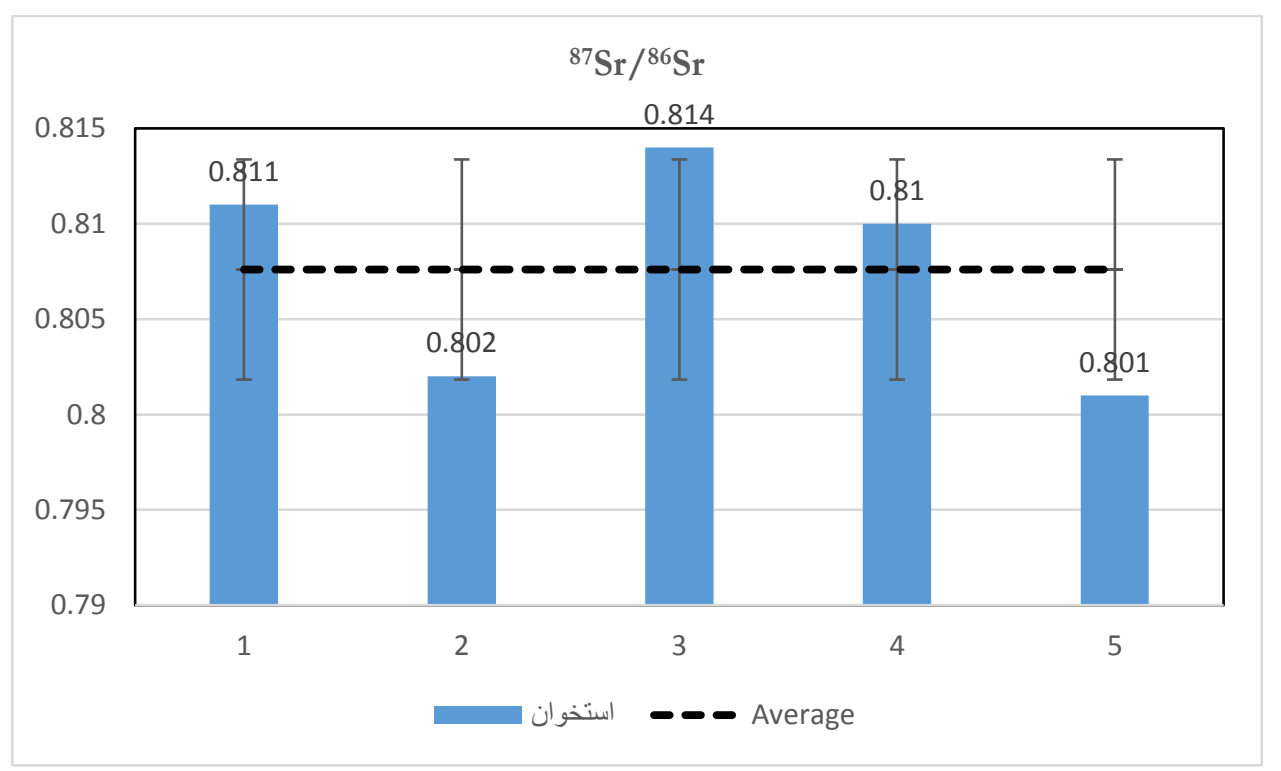

شكل ؤ نسبت

Fig. 6: Strontium ratio of the bones along with mean value (dashed black line) and the mean \pm 2 SDD bars 


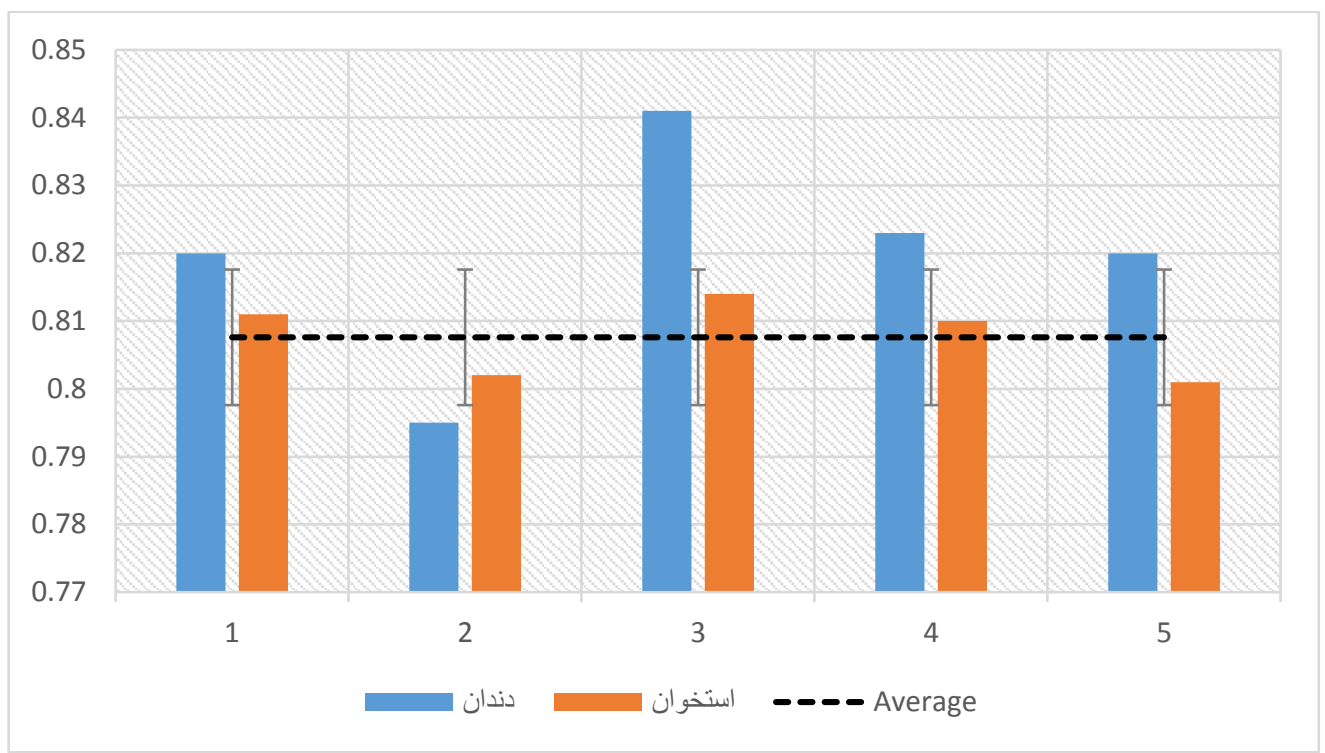

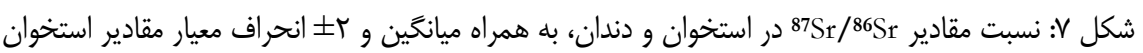

Fig. 7: Strontium ratio of the bones (orange) and tooth (blue) along with the mean value (Dashed black line)

البته در دست داشتن نسبت استرانسيوم منـاطق اطـراف و

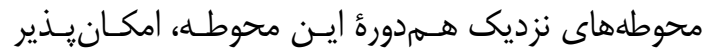

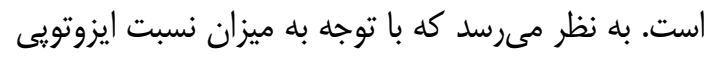

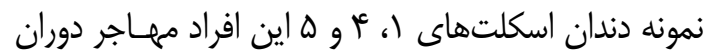
كودكى خود را در يك منطقه سبرى كردهاند كـه بـهـطـور

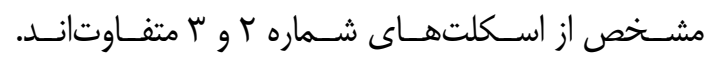

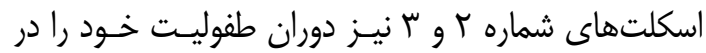

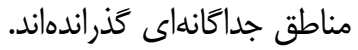

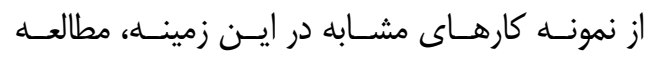

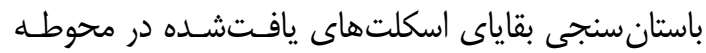
مسجد كبود تبريز است كه متعلق به عصر آهن است. اين

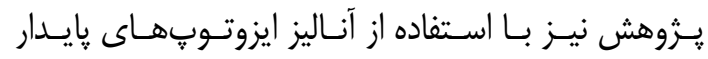

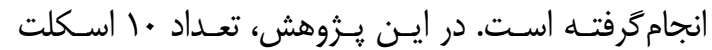

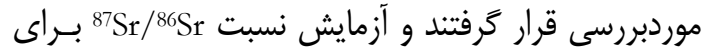

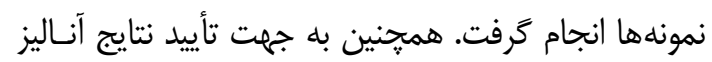

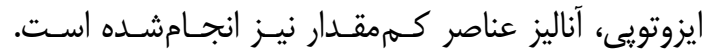

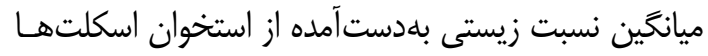
•D\& V .

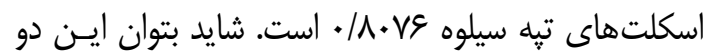

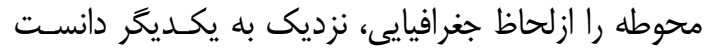

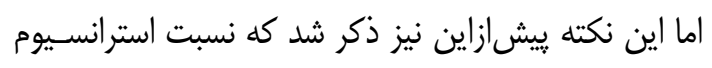

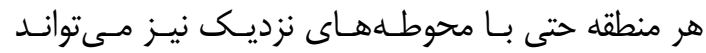

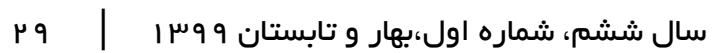

كوجّى به نظر مىرسد اما ازلحاظ زمـينشناسـى و نيـز

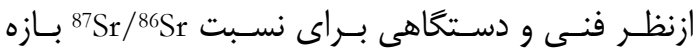

وسيعى را شامل مى شود [22].

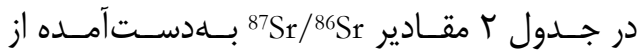

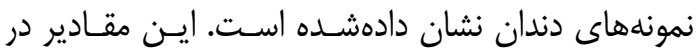

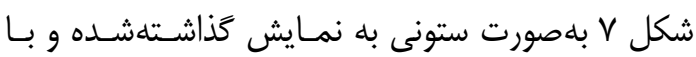
محدوده مربوط به نمونههاى محلى مقايسه شده است. جنانجه در شكل \ ديده مىشود، دندان اسكلت سوم

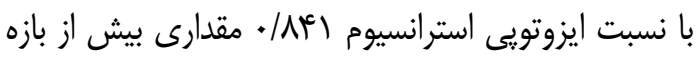
اطمينان را نشان مى دهـــ. همجنــين نسـبت نمونهُ دندانى اسكلت اول، جهارم و يُجنم نيز اندكى بـالاتر

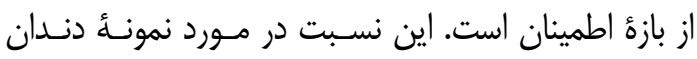

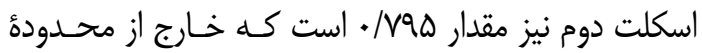
نمونههاى محلى محسوب مىشود. با توجه به ايـن نتـايج

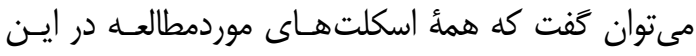
يزوهش، مربوط به افراد مهاجر هستند، زيرا ميزان نسـبت كمان

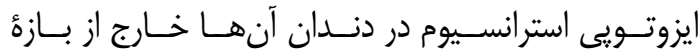
تعريفشده براى نمونههاى محلى است. البتـهـ تنهـا بـا در

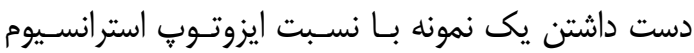

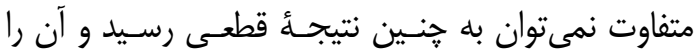

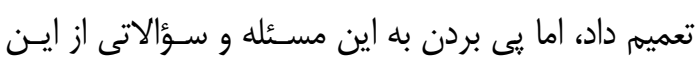

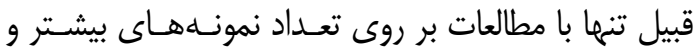


مىتوان همأ نمونهها را غيربومى در نظر گرَفت. البته ايـن

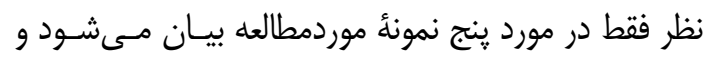

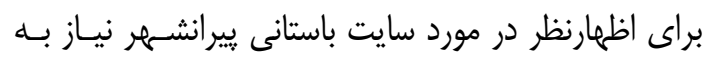
مطالعه و آزمايش نمونههاى بيشترى است.

\section{سباسگَزارى}

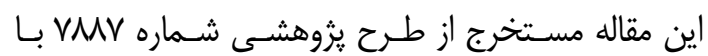

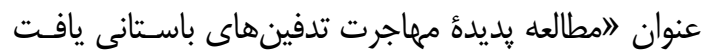

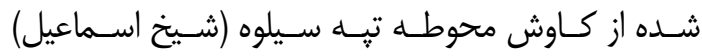
يبرانشهر" است كـه تحـت حمايـت مـالى دانشـحاه هنـر

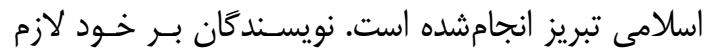
مى دانند كه از مساعدت و كمكـهاى همه جانبئ دانشـانهاه،

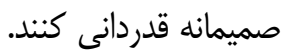

\section{ي بيىنوشتها}

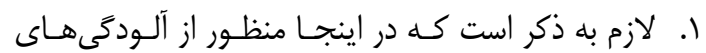

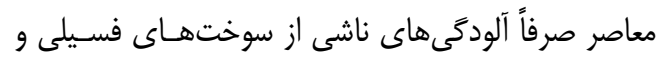

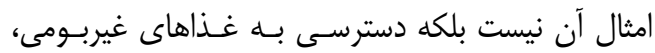

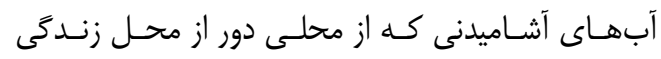

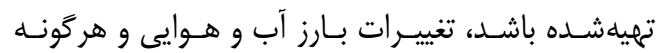

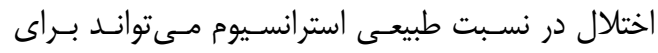
تحقيقات ايزوتويى استرانسيوم، آلودگى محسوب شود.

2. Confidence limit

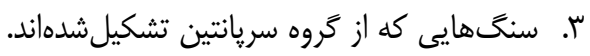

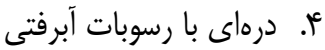

$$
\begin{aligned}
& \text { ه. برجستى هاى سطح جونده دندان } \\
& \text { و آب مقطر دو بار تقطير }
\end{aligned}
$$

7. \pm 2 S.D.

\section{References}

[1] Mays S. The archaeology of human bones. Routledge; 2010 Apr 21.

[2] Brown TA, Brown K. Biomolecular archaeology: an introduction. John Wiley \& Sons; 2011 Feb 8.

[3] Ericson JE. Strontium isotope characterization in the study of prehistoric human ecology. Journal of human evolution. 1985 Jul 1;14(5):50314.

[4] Dasch EJ. Strontium isotopes in
متفاوت باشـــ و تحـت تـأثير آبهــاى زيرزمينسى و نــوع سنگ

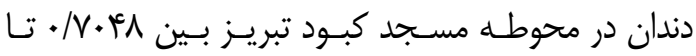

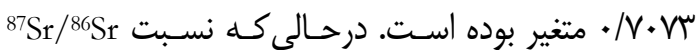

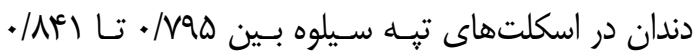

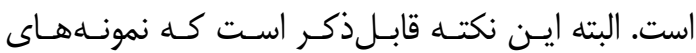
موردمطالعه از محوطه مسجد كبود تبريز متعلق بــهـ عصـر آهن بوده و قدمتى بسيار بيشتر از نمونههاى مطالعاتى تيه

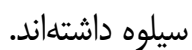

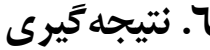

توجه بله نحوه و زمـان شـكل كَيــى سـاختار اسـتخوان و و

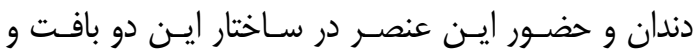

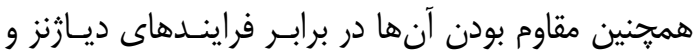

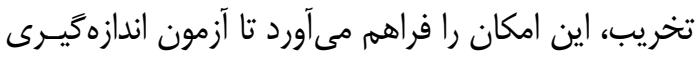

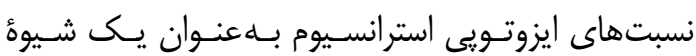

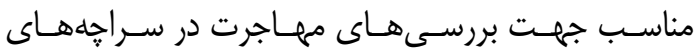

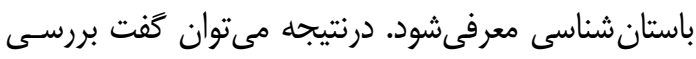

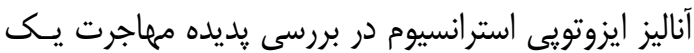
روش قابلاعتماد است.

با توجه به مطالعاتى كه در طى ايـن يـرَوهش انجـام

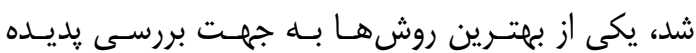

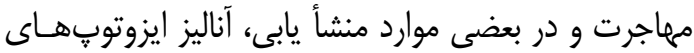

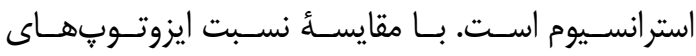

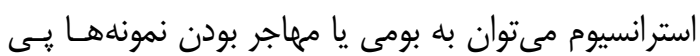

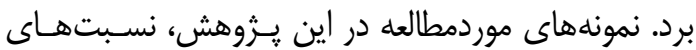

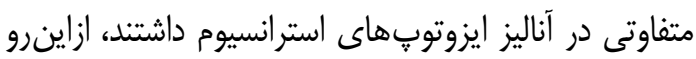

weathering profiles, deep-sea sediments, and sedimentary rocks. Geochimica et Cosmochimica Acta. 1969 Dec 1;33(12):1521-52.

[5] Hurst RW, Davis TE. Strontium isotopes as tracers of airborne fly ash from coalfired power plants. Environmental Geology. 1981 Nov 1;3(6):363-7.

[6] Sealy JC, van der Merwe NJ, Sillen A, Kruger FJ, Krueger HW. 87Sr86Sr as a dietary indicator in modern and

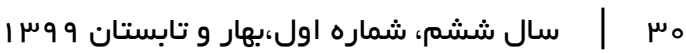


archaeological bone. Journal of Archaeological Science. 1991 May 1;18(3):399-416.

[7] Sillen A, Kavanagh M. Strontium and paleodietary research: a review. American Journal of Physical Anthropology. 1982;25(S3):67-90.

[8] Price TD, Burton JH, Bentley RA. The characterization of biologically available strontium isotope ratios for the study of prehistoric migration. Archaeometry. 2002 Feb;44(1):117-35.

[9] Harvig L, Frei KM, Price TD, Lynnerup N. Strontium isotope signals in cremated petrous portions as indicator for childhood origin. PloS one. 2014 Jul 10;9(7):e101603.

[10] Killgrove K. Biohistory of the Roman Republic: the potential of isotope analysis of human skeletal remains. Post-Classical Archaeologies. 2013;3(1):41-62.

[11] Shaw BJ, Summerhayes GR, Buckley HR, Baker JA. The use of strontium isotopes as an indicator of migration in human and pig Lapita populations in the Bismarck Archipelago, Papua New Guinea. Journal of Archaeological Science. 2009 Apr 1;36(4):1079-91.

[12] Bentley RA, Price TD, Stephan E. Determining the 'local'87Sr/86Sr range for archaeological skeletons: a case study from Neolithic Europe. Journal of Archaeological Science. 2004 Apr 1;31(4):365-75.

[13] Knudson KJ, Price TD, Buikstra JE, Blom DE. The use of strontium isotope analysis to investigate Tiwanaku migration and mortuary ritual in Bolivia and Peru. Archaeometry. 2004 Feb;46(1):5-18.

[14] Schweissing MM, Grupe G. Stable strontium isotopes in human teeth and bone: a key to migration events of the late Roman period in Bavaria. Journal of archaeological science. 2003 Nov
1;30(11):1373-83.

[15] Eckardt H, editor. Roman Diasporas: Archaeological approaches to mobility and diversity in the Roman Empire. Journal of Roman Archaeology; 2010.

[16] Kusaka, k., Ando, A., Nakano, N., Yumoto, T., Ishimaru, E., Yoneda, M., Hyodo, F., Katayama, K. 2009. A strontium isotope analysis on the relationship between ritual tooth ablation and migration among the Jomon people in Japan. Journal of Archaeological Science. 36, 2289-2297.

[17] Bocherens H, Mashkour M, Billiou D. Palaeoenvironmental and archaeological implications of isotopic analyses (13C, $15 \mathrm{~N})$ from Neolithic to Present in Qazvin Plain (Iran). Environmental Archaeology. 2000 Jun 1;5(1):1-9.

[18] Kheirkhah M, Mirnejad H. Volcanism from an active continental collision zone: A case study on most recent lavas within Turkish-Iranian plateau. J. Tethys. 2014;2(2):81-92.

[19] Paytan, A., Slovak, N.M. 2011. Application of Sr Isotopes in Archaeology. In: Handbook of Environmental Isotope Geochemistry, Verlag: Springer Berlin Heidelberg.

[20] Kasiri MB, Karimi HZ. Study of skeletons of the Iron Age cemetery of Tabriz by strontium isotopes analysis. Journal of Archaeological Science: Reports. 2017 Dec 1;16:359-64.

[21] Poirier, Y. et al., 2003. Isotope geochemistry in the oil \& gas exploration context: progress towards a bigh vertical resolution screening tool; Total SA. Fluids and Organic Geochemistry, Pau, France; Poster presented at: Applied Isotope Geochemistry-5, Heron Island, Australia, 26-30May, 2003.

[22] Price TD, Grupe G, Schröter P. Reconstruction of migration patterns in the Bell Beaker period by stable strontium isotope analysis. Applied Geochemistry. 1994 Jul 1;9(4):413-7. 